INTER NATIONAL MONETARY FUND

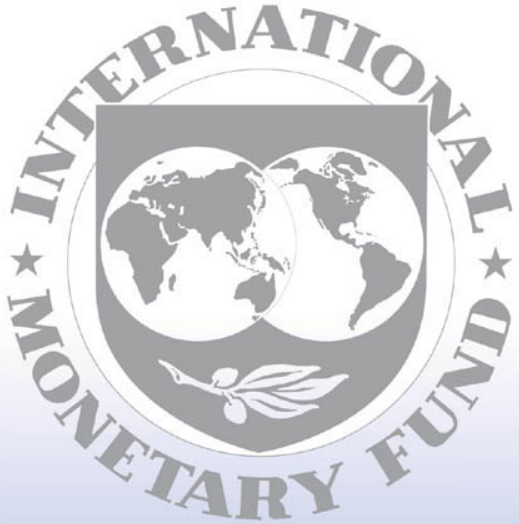

Staff

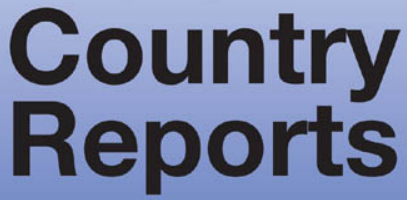




\section{Democratic Republic of Timor-Leste: 2009 Article IV Consultation-Staff Report; Public Information Notice on the Executive Board Discussion; and Statement by the Executive Director for the Democratic Republic of Timor-Leste}

Under Article IV of the IMF's Articles of Agreement, the IMF holds bilateral discussions with members, usually every year. In the context of the 2009 Article IV consultation with the Democratic Republic of Timor-Leste, the following documents have been released and are included in this package:

- The staff report for the 2009 Article IV consultation, prepared by a staff team of the IMF, following discussions that ended on June 16, 2009, with the officials of the Democratic Republic of Timor-Leste on economic developments and policies. Based on information available at the time of these discussions, the staff report was completed on July 8, 2009. The views expressed in the staff report are those of the staff team and do not necessarily reflect the views of the Executive Board of the IMF.

- A Public Information Notice (PIN) summarizing the views of the Executive Board as expressed during its July 22, 2009, discussion of the staff report that concluded the Article IV consultation.

- A statement by the Executive Director for the Democratic Republic of Timor-Leste.

The document listed below has been or will be separately released.

Selected Issues Paper

The policy of publication of staff reports and other documents allows for the deletion of market-sensitive information.

Copies of this report are available to the public from

International Monetary Fund • Publication Services

$70019^{\text {th }}$ Street, N.W. • Washington, D.C. 20431

Telephone: (202) 623-7430 • Telefax: (202) 623-7201

E-mail: publications@imf.org Internet: http://www.imf.org

\section{International Monetary Fund \\ Washington, D.C.}


This page intentionally left blank 


\author{
INTERNATIONAL MONETARY FUND \\ DEMOCRATIC REPUBLIC OF TIMOR-LESTE
}

Staff Report for the 2009 Article IV Consultation

Prepared by the Staff Representatives for the 2009 Consultation with Timor-Leste (In consultation with other departments)

Approved by James Gordon and Anthony Boote

July 8, 2009

- Article IV discussions took place in Dili during June 3-16, 2009. The mission met with President Ramos-Horta, Finance Minister Pires, General Manager of the Banking and Payments Authority Vasconcelos, other senior officials, and representatives of donors, the business community, and civil society.

- Team: Messrs. Schule (head) and Cubero (both APD), Ms. Takahashi (FAD), and Mr. Rasmussen (Resident Representative). Messrs. Cardoso (OED) and Sugden (Asian Development Bank) also joined the mission.

- The last Article IV Consultation was concluded in June 2008. The relevant documents may be found at http://www.imf.org/external/pubs/cat/longres.cfm?sk=22111.0. See also Appendix I.

- Exchange system: Timor-Leste uses the U.S. dollar as its official currency; its exchange rate regime is therefore classified as an arrangement with no separate legal tender. The country has accepted the obligations of Article VIII, Sections 2, 3, and 4, and maintains an exchange rate system free of restrictions on payments and transfers for current international transactions.

- Publication: The authorities indicated their intention to publish the staff report. A press statement was issued at the end of the consultation. 
Executive Summary

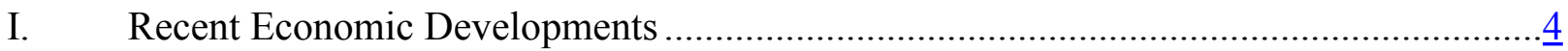

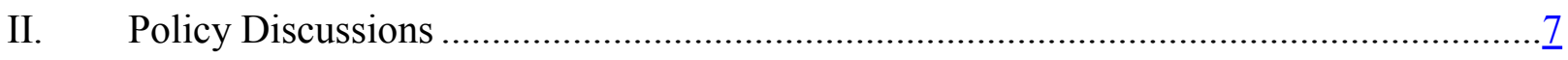

A. Outlook and Risks .................................................................................

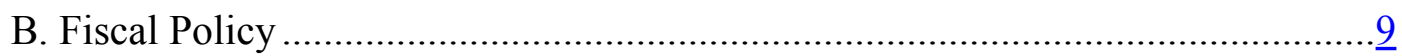

C. Financial Sector....................................................................................

D. Competitiveness, External Sustainability, and Exchange Rate Policy ………....13

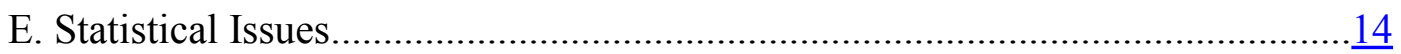

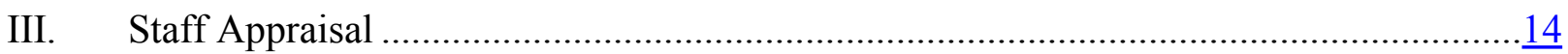

Boxes

1. The Impact of Oil Price Shocks on Oil Producing Countries ...........................................16

2. Exchange Rate, Competitiveness, and External Sustainability Assessment.....................17

3. Petroleum Fund Performance and Outlook................................................................

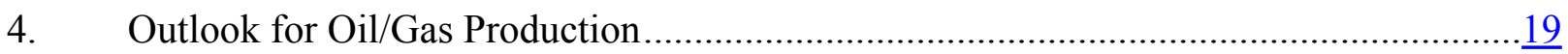

5. Timor-Leste's Petroleum Fiscal Regimes....................................................................

Figures

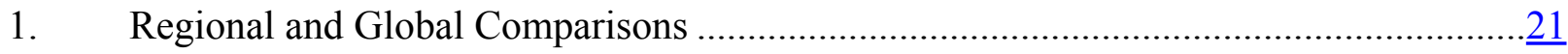

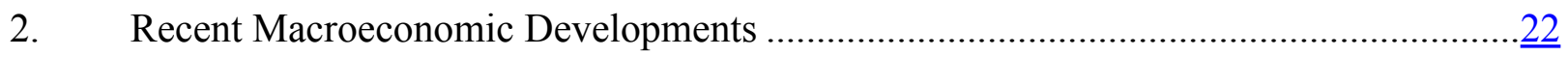

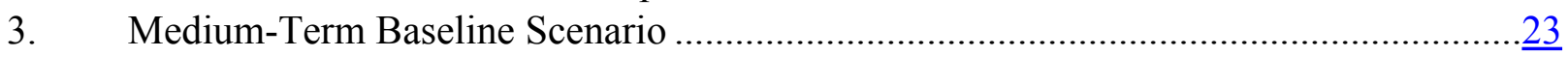

4. Developments in Government Wages and Salaries .....................................................

Tables

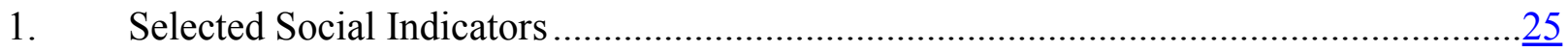

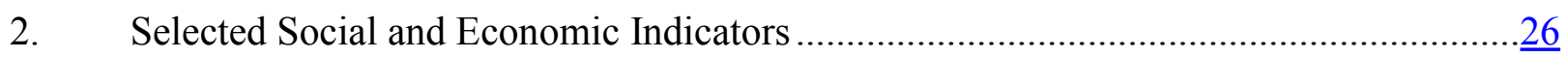

3. Central Government Budget, FY2004/05-2010 ………………………………........27

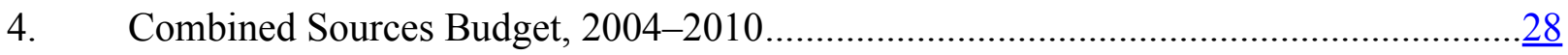

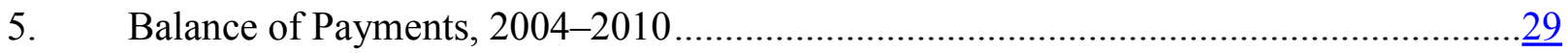

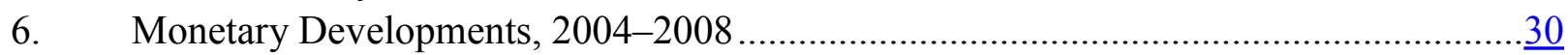

7. Medium-Term Outlook, 2006-2014 (Strong Policy Scenario) …………………….........

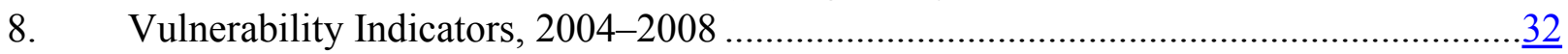

Appendix

I. Authorities' Response to Recent Fund Policy Advice....................................................33 


\section{Executive Summary}

Economic growth has been high over the last two years, fueled by oil-financed government spending and underpinned by improved security conditions. The global crisis has had no major impact on the domestic economy, given limited external linkages via trade, investment or finance. The key adverse impact has been through lower oil prices, which, if persistent, could reduce the sustainable level of public spending. While non-oil growth is expected to remain relatively high, the medium-term outlook is very uncertain, and contingent upon the path of petroleum revenue, the security situation, the magnitude and quality of public spending, and the progress on business-enabling reforms.

\section{The key policy challenge for Timor-Leste is to manage its petroleum wealth in a} sustainable fashion that stimulates the growth of the non-oil sector and supports poverty reduction. Along with soaring petroleum revenue, government spending has increased rapidly over the last two years. While this reflects efforts to address pressing needs and secure social cohesion, it cannot continue at the present pace. Staff welcomed the authorities' intention to moderate the speed of fiscal expansion as signaled in the 2010 Budget circular, and urged them to bring spending in line with the sustainable level by 2012.

Fiscal prudence is also needed to support external sustainability and help avoid real exchange rate appreciation. Official dollarization has helped contain inflation expectations, and staff recommended that the regime be maintained. To boost competitiveness, the mission underscored the need for productivity-enhancing public spending and reforms to improve the investment climate.

The mission stressed that the Petroleum Fund should remain the cornerstone for public financial management. The forthcoming revision to its law, intended to widen the Fund's investment portfolio, should leave intact the Fund's basic principles of transparency, accountability, and long-run sustainability. Any foreign borrowing, which the authorities are contemplating as an alternative to tapping the Fund, should be subject to these same principles. Staff recommended careful prioritization, sequencing, assessment and monitoring of public works, in line with a medium-term budget framework.

The financial sector remains at an embryonic stage. Commercial banks reach only a small part of the population, and place the bulk of deposits in foreign assets. Credit growth has stalled, dragged by a high share of nonperforming loans and the lack of clearly defined and enforceable property rights. Staff recommended the continued strengthening of financial supervision, and swift passage of legislation and reforms to promote financial development, including the land law. 


\section{RECENT ECONOMIC DEVELOPMENTS}

1. The Timorese economy has been growing rapidly over the last two years. TimorLeste remains one of the least developed countries in the world, with 50 percent of the population living in poverty in 2007 (Figure 1, Table 1, and Annex V). However, a marked improvement in security conditions, a rebound in agriculture from a 2007 drought, and a sharp increase in public expenditure have led to rapid economic growth since the civil unrest in 2006-07. Non-oil real GDP growth reached almost 13 percent in 2008. In per capita terms, real non-oil GDP has expanded by more than 14 percent over the last two years. Private investment in the nonoil sector, however, remains at very low levels, complicating the prospects for broadbased growth.

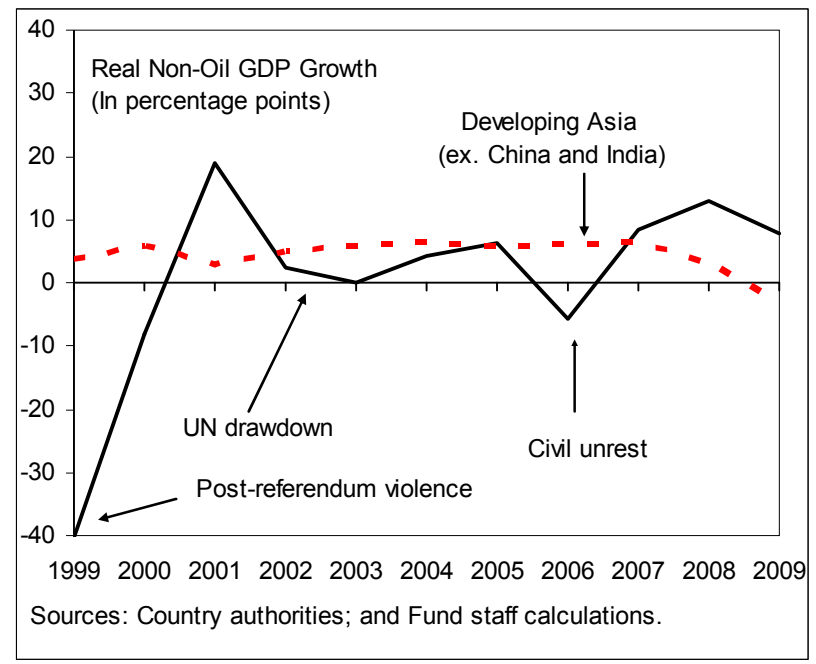

2. The global crisis has had limited immediate impact on Timor-Leste. Foreign investment outside the oil sector and non-oil exports remain very small. Also, the financial sector is at an embryonic stage, and the foreign parents of the three commercial banks are in a strong financial position. ${ }^{1}$ Thus, the key channels through which the crisis has spread across the globe - trade, investment, and finance - have played little role in Timor-Leste. Foreign aid flows have increased, and growth remains driven by public spending. As in other oil exporting countries, the key adverse impact has been through lower oil prices and a sharp fall in petroleum revenues (Box 1). If persistent, lower oil prices will reduce the sustainable level of public spending.

3. Inflation has declined, along with international food prices. Pushed by higher commodity prices, inflation surged from 2006 to mid-2008, peaking at over 10 percent yearon-year (y/y). Food prices, with a weight of 60 percent in the CPI, played a key role. The correction in commodity prices since then has led to a sharp reduction in headline inflation to 2.7 percent $y / y$ in March 2009, almost converging with non-food inflation (Figure 2). The depreciation of the Indonesian and Australian currencies vis-à-vis the U.S. dollar has led to a real exchange rate appreciation (Box 2), and helped abate inflationary pressures.

\footnotetext{
${ }^{1}$ Australia and New Zealand Bank (ANZ) and Caixa Geral de Depositos (a state-owned Portuguese bank) were included by Global Finance (February 2009) among the world's 50 safest banks. The Indonesian state-owned Bank Mandiri is also sound, with high levels of capital and liquidity.
} 
4. Petroleum revenue soared in 2008. Petroleum-related revenue (including interest from petroleum savings) almost doubled in 2008 to $\$ 2.4$ billion (about 5 times non-oil GDP). The main driver was the surge in international oil prices in the first half of 2008. But two other factors contributed: a 15 percent increase in production volumes, and a doubling of Petroleum Fund earnings on the back of a higher base and a conservative investment strategy (all in U.S. government bonds) that generated a 6.9 percent return (Box 3). Higher oil/gas revenue boosted the central government surplus to 384 percent of non-oil GDP in 2008, while Petroleum Fund assets reached \$4.2 billion and have continued rising in 2009.

5. Central government spending increased substantially in 2008, reflecting efforts to address pressing needs and secure social cohesion. A key contributor was rice subsidies, reflecting large rice imports for subsidized resale to local retailers. Proportionally, however, the increase was particularly significant in capital spending and current transfers, including cash payments to displaced persons and pensions for veterans and the elderly. The surge in spending reflects a marked improvement in budget execution rates. Nonetheless, on a cash basis, spending was broadly

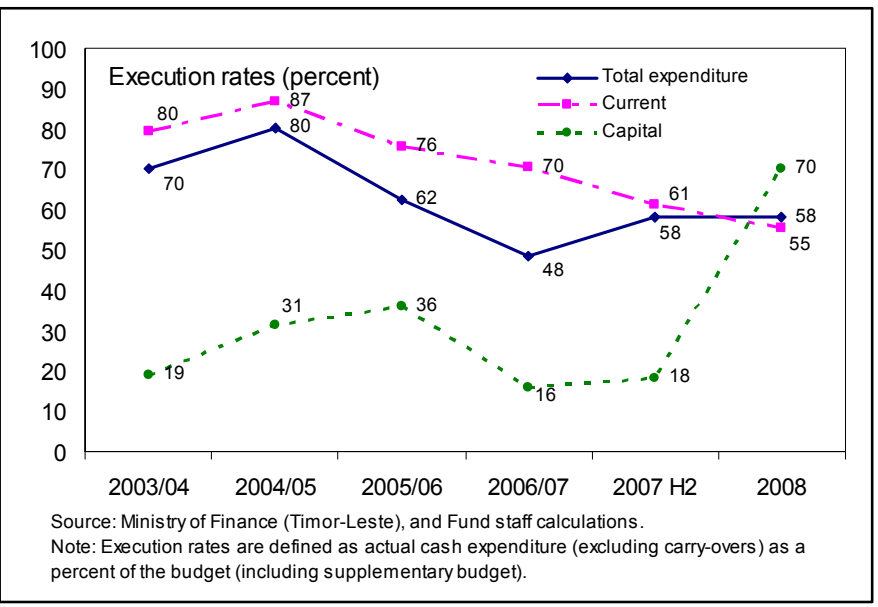
in line with its sustainable level — defined as the sum of non-oil revenue and the estimated sustainable income (ESI) from petroleum - and withdrawals from the Petroleum Fund have remained within the limit. ${ }^{2,3}$

\footnotetext{
${ }^{2}$ See footnote 2 of text figure on page 8 .

${ }^{3}$ ESI is calculated as the level of withdrawals from the Petroleum Fund that would stabilize the net present value of the Fund's assets. The calculation is updated each year as an input for the budget, and by law must be based on prudent oil price and volume assumptions.
} 

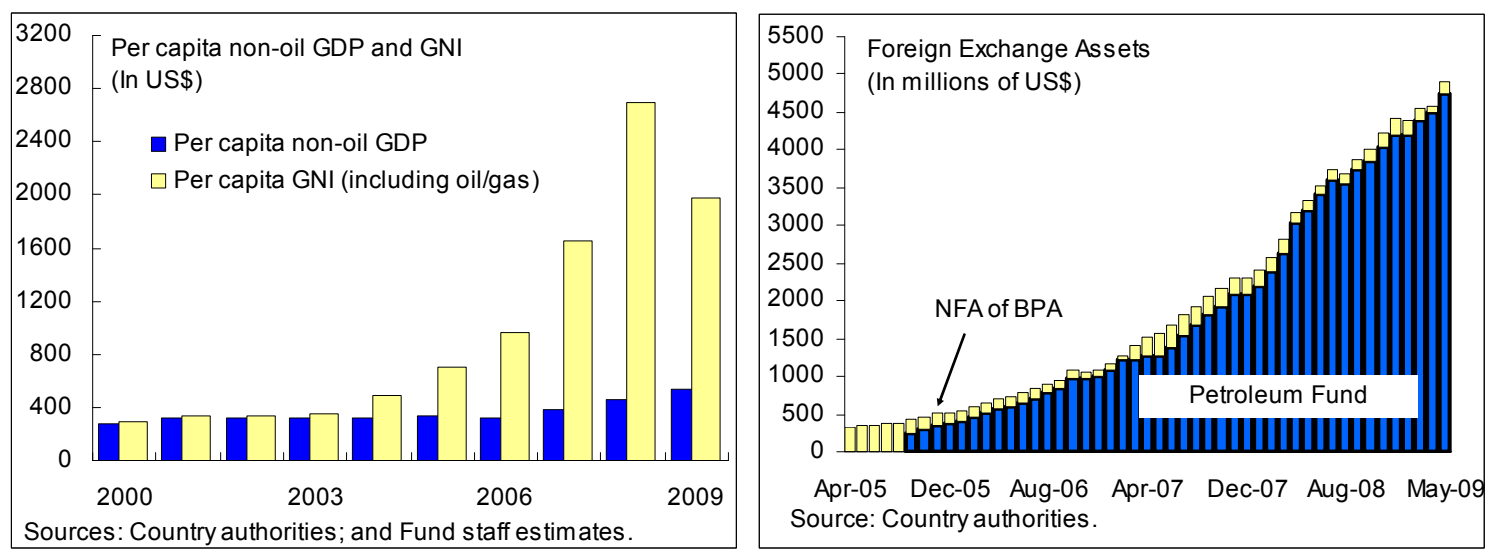

6. High oil and gas prices pushed the external current account surplus to about four times non-oil GDP in 2008. The current account remains driven by petroleum receipts (reflected as income in the current account ${ }^{4}$ ), which finance a large trade deficit. Higher public spending caused merchandise imports to soar in 2008, while exports (mainly coffee and tourism) remained small (Figure 2).

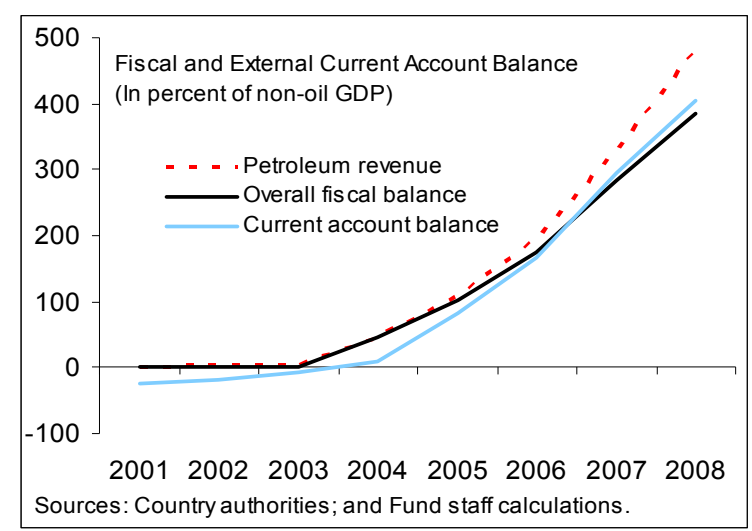

7. The financial sector is at an early stage of development. The three commercial banks, which are branches of foreign parents, reach only a small segment of the population. While deposits have been increasing on the back of faster growth in the non-oil economy, private sector credit has been stagnant since late 2005, and the spread between lending and deposit rates is high (about 11 percent). Loans account for under one-third of bank assets, with surplus funds held mainly in liquid assets abroad. A large share of loans is in arrears (27 percent), but covered twice over by provisions. ${ }^{5}$ Key impediments to credit are the lack of clear property rights and ineffectual contract enforcement. In this environment, microfinance has shown considerable potential (see Annex VI). A state-owned microfinance institution (IMfTL) has experienced substantial growth in credit, but remains a small player.

\footnotetext{
${ }^{4}$ See Table 5, footnote 1.

${ }^{5}$ As branches of foreign parents, commercial banks are not subject to capital adequacy requirements. IMfTL has capital well above the regulatory minimum.
} 

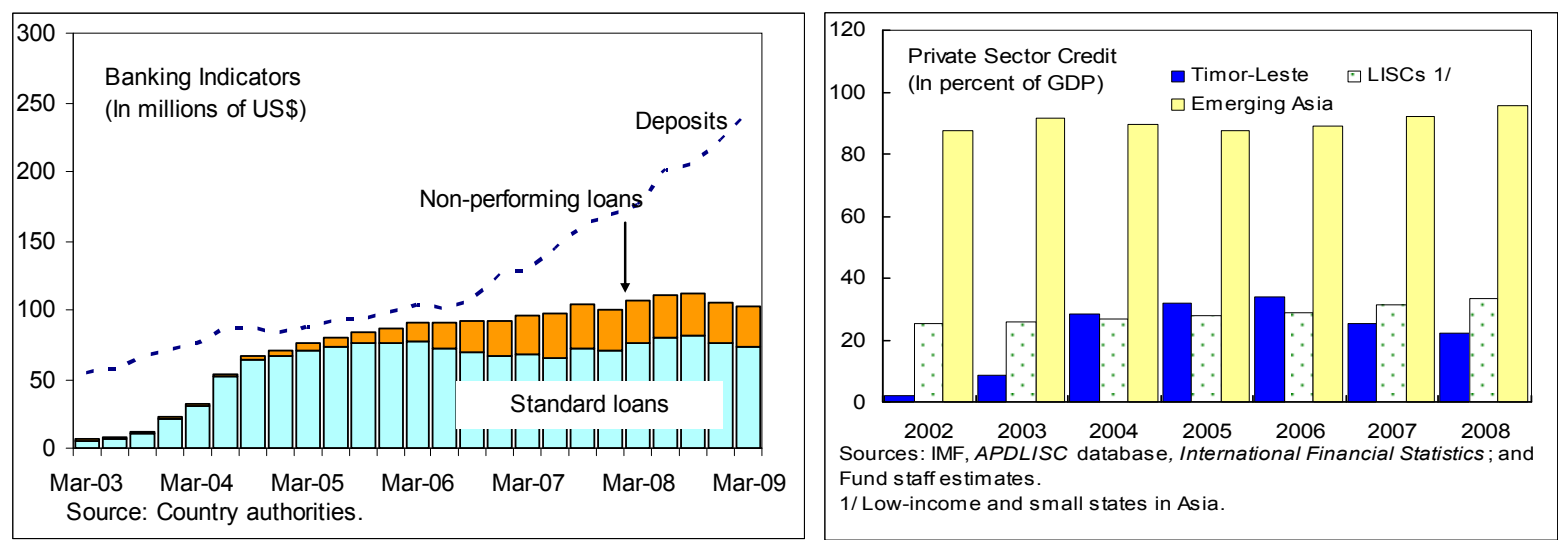

\section{Policy Discussions}

8. Discussions focused on the outlook and the policies needed to ensure mediumterm macroeconomic and financial stability, promote private sector growth, and support poverty reduction. In particular, the discussions centered on:

- $\quad$ the near and medium-term projections;

- $\quad$ ensuring fiscal sustainability and improving the efficiency and quality of public spending;

- $\quad$ policies to maintain the stability and promote the development of the financial sector;

- $\quad$ external sustainability and reforms to spur competitiveness and private investment.

\section{A. Outlook and Risks}

9. The near-term outlook for the Timorese economy is still positive, though marked by a sharp decline in the fiscal and external surpluses. Staff project a slowdown in central government expenditure growth to about 13 percent in 2009 and 4 percent in $2010 .^{6}$ However, spending would remain above the sustainable level. Real non-oil GDP growth would moderate to about $7 \frac{1}{2}$ percent in 2009-10, supported by public spending and private investment. Inflation is projected to stay at low single digit levels. Despite their recent recovery, oil prices are expected to remain below their 2008 average, triggering a sharp decline in the fiscal and current account surpluses.

\footnotetext{
${ }^{6}$ The 2010 projection is based on the limit set for the 2010 Budget (\$637 million for the general government; $\$ 622$ million for the central government). The actual increase in cash spending in 2009 is likely to be larger than reported in Table 3.
} 


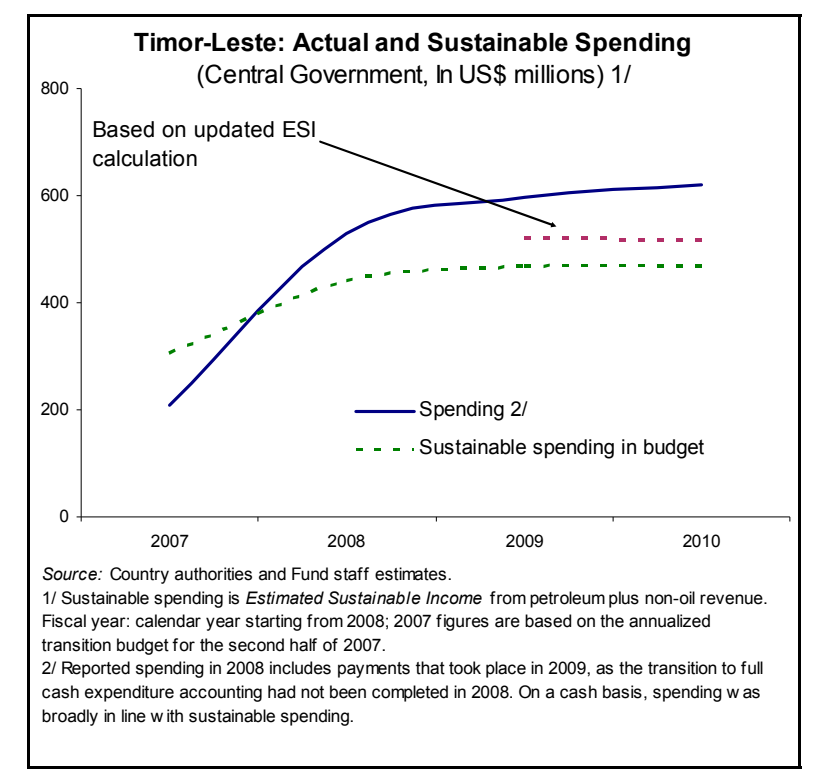

10. For the medium term, staff projects moderating but still high economic growth, and a slight improvement in the non-oil fiscal balance:

- $\quad$ Absent a well-defined medium-term budget framework, projections are complicated by unclear timing and cost of spending initiatives. In the staff's baseline ("strong policy") scenario, public spending is projected to peak in 2010 and return to the sustainable spending path by 2012. The non-oil fiscal deficit would halve between 2008 and 2014, to about 45 percent of non-oil GDP, while Petroleum Fund assets would continue expanding. The scenario also assumes significant improvement in the business environment and the quality and composition of public spending. This would support economic growth of about 6-7 percent per year over 2011-14, as growth converges to long-term fundamentals (productivity and labor supply). Headline inflation should remain low, barring any large external shocks. The current account surplus would fall along with petroleum revenues, unless new oil/gas fields come on stream. Merchandise imports are projected to fall as a share of non-oil GDP, reflecting less import-intensive public spending. Non-oil exports would remain small. With donor budgets under pressure and an improving security situation, external assistance is assumed to decline over the medium term.

- In an alternative, "weak policy" scenario, which is based on an extrapolation of recent (2006-08) public spending trends and assumes no major reforms to improve the business climate, non-oil GDP growth would be lower, government spending would continue to diverge from the sustainable level, the non-oil deficit would continue to increase, and the Petroleum Fund would eventually be depleted.

\section{The medium-term outlook is highly uncertain, with important risks on the}

upside and downside. Key uncertainties pertain to the path of oil and gas revenue, which depends on both volatile international prices and still uncertain production potential; security 
Timor-Leste: Medium-Term Macroeconomic Framework

\begin{tabular}{|c|c|c|c|c|c|c|c|c|}
\hline \multirow{5}{*}{$\begin{array}{l}\text { Real non-oil GDP growth (percent) } \\
\text { CPI inflation (percent, year average) } \\
\text { Non-oil balance of the central government } 1 / \\
\text { Petroleum Fund assets (US\$ millions) } \\
\text { Current account balance } 1 /\end{array}$} & \multicolumn{8}{|c|}{ Strong policy scenario } \\
\hline & 2008 & 2009 & 2010 & 2011 & 2012 & 2013 & 2014 & 2020 \\
\hline & 7.6 & 4.0 & 4.0 & 4.0 & 4.0 & 4.0 & 4.0 & 4.0 \\
\hline & 4,197 & 5,109 & 6,197 & 7,888 & 9,871 & 11,608 & 13,435 & 24,134 \\
\hline & 404.8 & 190.9 & 171.0 & 234.0 & 239.9 & 190.3 & 182.9 & 97.3 \\
\hline & \multicolumn{8}{|c|}{ Weak policy scenario } \\
\hline Real non-oil GDP growth (percent) & 12.8 & 7.9 & 9.2 & 6.6 & 6.5 & 6.0 & 5.5 & 3.5 \\
\hline CPI inflation (percent, end-period) & 7.6 & 4.0 & 4.0 & 4.0 & 4.0 & 4.0 & 4.0 & 4.0 \\
\hline Non-oil balance of the central government 1 / & -96.8 & -96.1 & -121.1 & -126.8 & -130.8 & -132.8 & -132.8 & -119.7 \\
\hline Petroleum Fund assets (US\$ millions) & 4,197 & 5,109 & 5,859 & 7,028 & 8,213 & 8,952 & 9,583 & 9,267 \\
\hline Current account balance $1 /$ & 404.8 & 183.4 & 135.5 & 167.6 & 133.6 & 73.1 & 56.4 & -41.6 \\
\hline
\end{tabular}

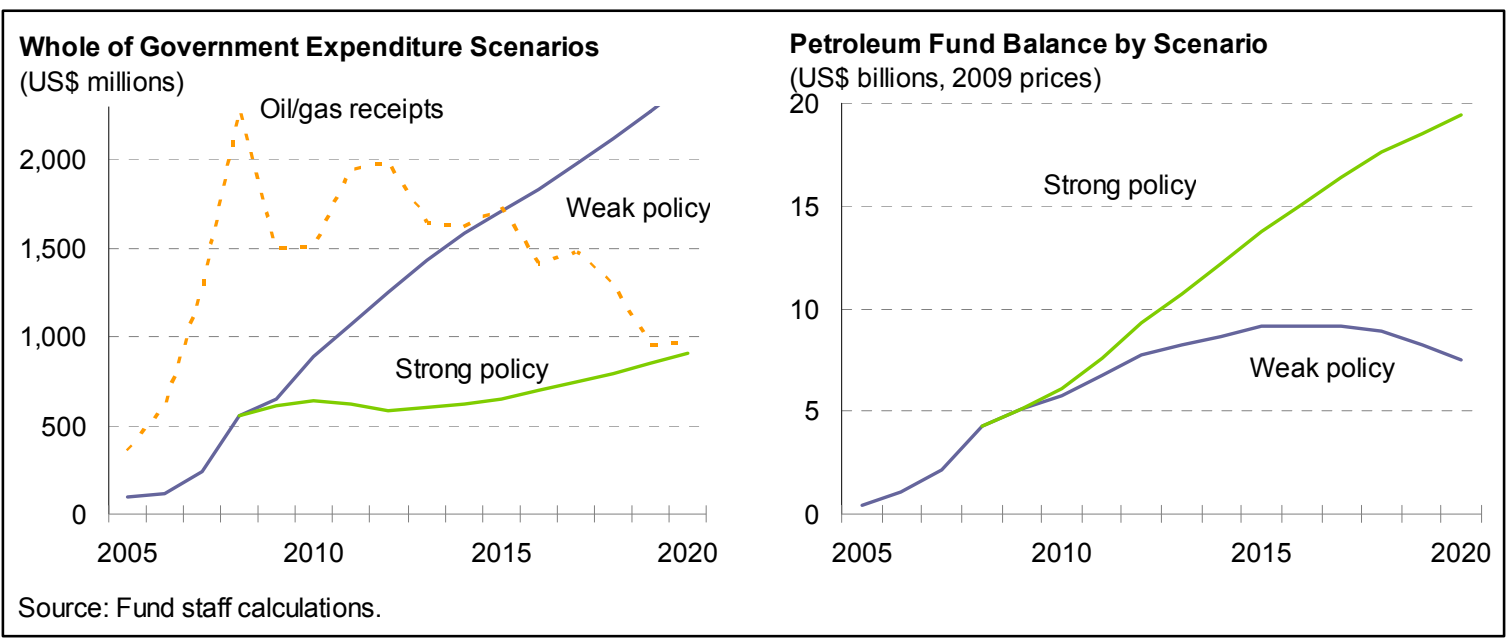

and political stability; the magnitude and quality of public spending; and the pace and significance of reforms to improve the business environment.

12. The authorities broadly agreed with the staff's near-term outlook, but were more optimistic about medium-term growth. In particular, they noted that reform efforts, well-targeted spending, and private investment will support double-digit real GDP growth. They were also optimistic about the prospects for revenue from future oil, gas, and other mineral developments.

\section{B. Fiscal Policy}

13. Oil and gas provide the country with considerable wealth, although not enough to make it rich. The net present value of the country's proven petroleum wealth, comprising 
the Petroleum Fund balance and discounted future revenue streams, is estimated at about $\$ 15.2$ billion (about $\$ 14,000$ per capita). ${ }^{7}$

14. The key fiscal challenge for Timor-Leste is to manage its petroleum wealth in a sustainable fashion that stimulates non-oil growth and supports poverty reduction.

Achieving these objectives requires a medium-term strategy to: (i) ensure the sustainability and improve the quality of spending; (ii) strengthen fiscal revenue; and (iii) improve public financial management.

\section{Sustainability and Quality of Public Spending}

\section{Staff welcomed the authorities' intention to moderate the pace of fiscal}

expansion. The 2010 envelope is consistent with the staff's "strong policy" scenario. It entails significant cuts in goods and services (30 percent) and minor capital (65 percent) and no change in outlays for wages and salaries relative to the 2009 Budget, while allowing for an increase in capital investment (most of which is contractually committed to a large electricity project).

\section{The mission urged the authorities to bring public spending in line with the} sustainable level by 2012. Spending in 2009-10 is projected to exceed the sustainable level by $15-20$ percent. This may be necessary to accommodate existing contracts. However, oneoff expenditures - such as payments to resettle displaced persons - and lower commodity prices (which allow for a reduction in rice subsidies) generate opportunities for considerable future savings. A continued commitment to wage restraint would also be helpful. This should allow spending to be brought back to the sustainable path by 2012, while:

- $\quad$ Keeping spending on a smooth upward path. More rapid increases in spending, as illustrated in the staff's weak policy scenario, could eventually deplete the country's petroleum wealth, forcing the government to engage in large-scale borrowing or drastically cut spending. This could undermine private investment and growth.

- $\quad$ Reducing the need for larger adjustments in the future, as this would help boost the Petroleum Fund assets and their considerable interest income.

- $\quad$ Providing ample space to address immediate social and security needs as well as for priority infrastructure spending.

\section{Public spending should be prioritized and targeted to promote growth and} reduce poverty. Recent increases in spending have provided a significant boost to aggregate demand and employment. Also, transfers to resettle internally displaced people and rice

\footnotetext{
${ }^{7}$ The figure would of course go up if new oil/gas fields come on stream.
} 
subsidies have helped strengthen peace and stability. Going forward, a key challenge will be to improve public spending efficiency and to strengthen transparency and monitoring to reduce the risk of abuse and corruption. Spending on health, education, security, and infrastructure should be prioritized (see Annex V). Transfers and subsidies should be reduced and diverted toward more efficient and welfare-enhancing uses, such as the expansion of the cash-for-work program and pensions to the elderly. Subsidy policies, including for food and electricity, should consider their distortionary impact and include exit strategies. The mission recommended adopting a tariff structure for electricity aimed at full recovery of operational costs, with concessions only for the neediest.

\section{The authorities noted the temporary nature of recent spending increases, and} stressed their commitment to fiscal sustainability. They argued that rapid spending increases to date reflected improvements in execution capacity and were justified by security and other pressing needs. They did not commit to the staff's recommended fiscal path beyond 2010, but were confident that revenue from new oil/gas fields or other mineral resources will increase sustainable spending levels above current projections.

\section{Revenue Generation}

19. The mission recommended measures to boost fiscal revenue. Staff welcomed recent efforts by the authorities to assess and optimize the taxation of oil and gas (Box 5). Despite the tax rate cuts implemented in mid-2008, domestic tax revenue increased in 2008 along with an expanded base. However, at about 8 percent, the tax to non-oil GDP ratio is lower than in other low and middle-income oil exporting countries and the low-income country group as a whole (chart below and Box 3). Staff encouraged the authorities to step up efforts to improve tax administration and combat evasion, for instance by reconciling customs and income tax information. Broadening the tax base by rationalizing investment incentives should also be considered.

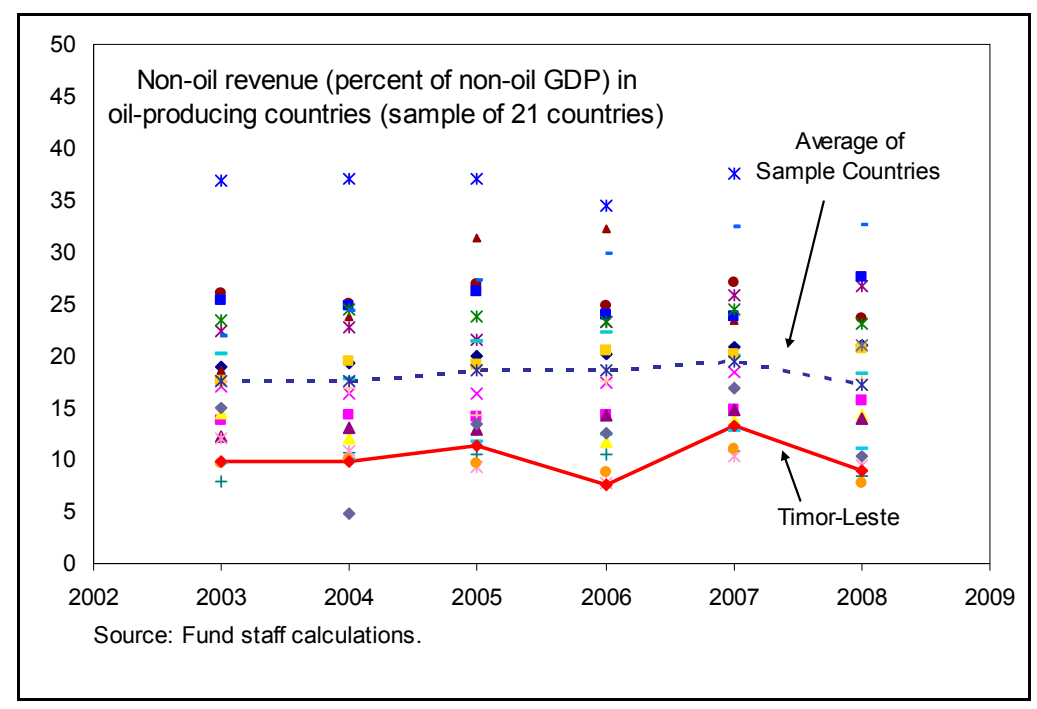




\section{Public Financial Management}

20. The mission stressed the need to retain the Petroleum Fund as the cornerstone for managing the country's oil-based resources. The Petroleum Fund insulates spending from volatile revenue flows, provides a framework for transparency and accountability, promotes long-run sustainability, and reduces pressures on the economy's absorption capacity (Box 2). According to the Fund's law, limits on its investment portfolio must be revisited in 2010; the authorities are considering a more diversified investment strategy as well as other possible changes to the law. Staff suggested moving cautiously, to allow time for gaining experience in managing riskier assets. The authorities stated that any reform to the Fund law would leave intact its basic principles.

\section{Any foreign borrowing should be subject to public scrutiny and its effective cost} carefully weighed. Some elements in government are considering borrowing from multilateral or bilateral official sources to fund infrastructure projects, as an alternative to tapping the Petroleum Fund. While the impact on the country's net wealth would be the same, foreign loans could be cost-effective if based on concessional terms and accompanied by technical assistance. The mission recommended that any such borrowing: (i) be transparent and subject to parliamentary approval; and (ii) takes carefully into account all terms and conditions of the loan, including non-interest costs.

\section{Staff welcomed the authorities' efforts to improve public financial management.} These include moving to cash-based budgeting, adopting monitorable performance targets, introducing a macroeconomic framework for medium-term projections to help guide policy, and preparing a strategic development plan that would set out the key policy objectives. To make this plan operational, the mission recommended: (i) subjecting project design to prioritization and careful cost-benefit analyses, including of recurrent costs; (ii) introducing a medium-term fiscal framework with clear links to the budget; (iii) improving the monitoring and auditing of projects; and (iv) stepping up capacity building on procurement, budget execution, and auditing at the line ministry level, and ahead of any decentralization to district-level governments. The authorities requested an extension of the IMF-funded treasury advisor, a fiscal Report on the Observance of Standards and Codes (ROSC) mission, and a Public Expenditure and Financial Accountability (PEFA) assessment.

\section{Financial Sector}

23. The mission recommended the continued strengthening of financial supervision. In particular, staff pointed to the need to strengthen data collection and analysis for prudential supervision, as well as on-site and off-site surveillance methods. Staff also encouraged the authorities to strengthen cooperation, including through memoranda of understanding, with the home supervisors of foreign banks.

24. The mission encouraged the passage of legislation and reforms needed to promote financial sector stability and development. Priorities include the land law, the 
central bank law to safeguard the Banking and Payments Authority's (BPA) operational autonomy, and passing other important financial sector legislation (banking, payments, antimoney laundering) and insurance regulations. The authorities reiterated their commitment to table these reforms, but observed that the country is young and faces a very large institutionbuilding and legal framework agenda. They also expressed interest in providing subsidized credit, either directly or in cooperation with private financials. Staff recommended that any public sector involvement in the financial sector be subject to transparency checks and the same regulatory and supervisory standards as commercial banking activities.

\section{Competitiveness, External Sustainability, and Exchange Rate Policy}

\section{Given official dollarization, fiscal policy is essential to ensure external}

sustainability. Standard analyses of exchange rate misalignment are neither feasible nor very meaningful for Timor-Leste. The lack of data leaves little scope for econometric techniques. The current account is mainly driven by oil/gas revenue developments, and is therefore likely to be relatively inelastic to the real exchange rate. ${ }^{8}$ The medium-term sustainability of the current account is primarily a function of fiscal policy: keeping spending on a sustainable path supports external sustainability directly, by reducing imports, and indirectly, by helping to avoid a real exchange rate appreciation through demand-driven inflation.

\section{A key problem for Timor-Leste is weak structural competitiveness. Broader} indexes of competitiveness and ease of doing business indicate that the business environment remains uncompetitive, even by the standards of other low income countries (Box 1). In addition to boosting productivity-enhancing public spending, staff and the authorities agreed on the need to pass the pending land law, resolve conflicting claims on land, and improve contract enforcement through judicial reform and the adoption of an alternative dispute resolution framework. These are essential steps to promote private investment and bank lending. Lighter business regulations, including simplified registration and licensing procedures, are also important. The mission welcomed the authorities' initiative to establish a one-stop-shop for investors. The commitment to public wage restraint in the 2010 Budget envelope should also help private sector development by lowering the cost of attracting skilled labor (Figure 4).

\section{The authorities remain committed to retaining the current exchange rate} regime. Official dollarization has served the country well: it has provided a strong nominal anchor for inflation expectations and eliminated the possibility of speculative attacks on the domestic currency. The introduction of a new currency, particularly under a flexible

\footnotetext{
${ }^{8}$ Petroleum revenue is by far the largest source of income and the main driver of imports. The non-oil export sector is very small and concentrated in crop commodities (particularly coffee) that tend to be largely determined by supply factors. Among the main components of the current account, tourism is likely to be the most sensitive to the real exchange rate.
} 
exchange rate regime, would require the existence of relatively developed financial markets, entail the risk of currency substitution (at least initially), and drive scarce administrative capacity away from more pressing needs.

\section{E. Statistical Issues}

28. Data provision continues to have shortcomings, especially on national accounts, that significantly hamper macroeconomic analysis and surveillance (Annex IV). Moderate progress has been made, however, to enhance data quality and provision. In particular, staff noted recent progress in the collection and coverage of monetary and financial statistics, and welcomed the recent publication of monetary and balance of payments statistics. The mission encouraged the authorities to allocate sufficient resource to improve economic data, to give priority to annual household income and expenditure surveys as an essential input for constructing expenditure-based national accounts, and to participate in the IMF's General Data Dissemination System.

\section{Staff Appraisal}

\section{Non-oil GDP growth will remain high in the near term, with little immediate} adverse effects from the global crisis. Rapid increases in government spending, together with improved security and a good harvest, pushed non-oil GDP growth up in 2007-08. Growth is expected to remain high in the near term, supported by public spending and private investment, while limited external linkages via trade, investment or finance will keep the non-oil economy relatively isolated from the global crisis. In the medium run, growth will gradually converge to supply-side fundamentals. The decline in commodity prices since their peak in mid-2008 will narrow Timor-Leste's fiscal and external position over the medium term, unless new oil/gas fields come on stream.

\section{Public spending should return to a sustainable path over the medium term, and} be targeted to growth promotion and poverty reduction. With public spending already in 2009 above the sustainable level, further rapid increases would eventually deplete the Petroleum Fund. The recently announced moderation in government spending growth, including wages, is welcome. Consistent with it, government spending should be brought in line with a sustainable path as soon as existing commitments allow. The efficiency and targeting of spending should also be improved, so as to create room for strengthened spending on health, education, infrastructure, and poverty-reducing transfers.

\section{Fiscal prudence is also needed to support competitiveness and external} sustainability. Moderate public spending increases would keep the current account on a sustainable path and reduce pressure on the real exchange rate. Productivity-enhancing spending, and reforms to improve the business climate, are crucial to boost competitiveness. Official dollarization has helped keep inflation under control, and should be maintained. 


\section{Staff recommends that the Petroleum Fund remain at the center of petroleum-} based revenue management. Its key principles - that all petroleum revenues go to the Fund, and that withdrawals go through the budget and are consistent with wealth preservation for future generations - should remain intact, as they safeguard transparency and sustainability, and protect spending from revenue volatility. A medium-term expenditure framework should be introduced, and capital investment projects should be carefully prioritized and costed. Any foreign borrowing should be subject to Parliamentary approval and proper justification.

\section{Continued efforts are needed to strengthen financial sector supervision and} promote financial development. The banking sector is small and has not been adversely affected by the global financial turmoil, but it is important to step up measures to improve financial supervision, strengthen cooperation with home supervisors of foreign banks, and pass legislation to safeguard the Banking and Payments Authority's autonomy. Reforms to enhance property rights are also needed to promote financial development.

34. Staff recommends that the next Article IV consultation be held on the standard 12month cycle. 


\section{Box 1. The Impact of Oil Price Shocks on Oil Producing Countries}

A cross-country study by the Fund's Fiscal Affairs Department analyzes fiscal vulnerability in oil producing countries to sharp declines in oil prices. ${ }^{1}$

Increases in oil prices until mid-2008 improved overall fiscal positions in oil producing countries (OPCs). The sample of 21 mostly low and middle-income OPCs recorded growing fiscal surpluses between 2003 and 2008, when average annual oil prices increased from about US\$30 to nearly US $\$ 100$ per barrel. The average overall surplus for the sample of countries rose from 2.6 percent of non-oil GDP in 2003 to 15.0 percent of non-oil GDP in 2007, and is estimated to have increased further to 31.4 percent of non-oil GDP in 2008.

In contrast, the average nonoil primary position deteriorated. On average, OPC governments spent about half of the increase in oil revenue accumulated between 2004 and 2008. Consequently, the average non-oil primary deficit increased from around 20 percent of non-oil GDP in 2004 to nearly 30 percent in 2008. Primary expenditure increases during this period were driven mainly by capital expenditure, which grew from an average of 15 percent of non-oil GDP to 30 percent.

\begin{tabular}{|c|c|c|c|c|}
\hline \multicolumn{5}{|c|}{ Overall Fiscal Balance and Oil Revenue for a Sample of Oil Producing Countries, 2008} \\
\hline \multirow[b]{2}{*}{ Country } & \multicolumn{2}{|c|}{$\begin{array}{c}\text { Overall Fiscal Balance } \\
\text { (percent of non-oil GDP) }\end{array}$} & \multicolumn{2}{|c|}{ Oil (resource) Revenue } \\
\hline & $\begin{array}{c}\text { Prel. } \\
\text { (US\$97 per barrel) }\end{array}$ & $\begin{array}{c}\text { Simulation } \\
\text { (US } \$ 60 \text { per barrel) }\end{array}$ & $\begin{array}{l}\text { in percent of } \\
\text { non-oil GDP }\end{array}$ & $\begin{array}{l}\text { in percent of } \\
\text { total revenue }\end{array}$ \\
\hline Vietnam & -4.7 & -6.9 & 5.8 & 21.7 \\
\hline Indonesia & -0.1 & -2.6 & 6.4 & 29.2 \\
\hline Cameroon & 2.7 & -0.7 & 8.7 & 40.0 \\
\hline Mexico & -2.1 & -6.1 & 10.6 & 36.8 \\
\hline Ecuador & 3.0 & -2.1 & 13.1 & 32.8 \\
\hline Kazakhstan & 1.5 & -4.6 & 15.9 & 40.2 \\
\hline Sudan & -3.0 & -9.4 & 16.7 & 66.2 \\
\hline Russia & 7.1 & 0.6 & 17.0 & 32.4 \\
\hline Iran & -2.3 & -11.5 & 24.0 & 68.7 \\
\hline Venezuela & 0.4 & -10.7 & 29.1 & 33.1 \\
\hline Trinidad and Tobago & 11.6 & -3.0 & 37.8 & 57.8 \\
\hline Yemen & -8.2 & -23.6 & 40.0 & 73.5 \\
\hline Gabon & 22.3 & 6.3 & 41.4 & 64.3 \\
\hline Nigeria & 6.1 & -9.9 & 41.7 & 81.3 \\
\hline Chad & 10.2 & -6.7 & 43.8 & 85.9 \\
\hline Algeria & 15.5 & -10.9 & 68.6 & 79.4 \\
\hline Azerbaijan & 44.0 & 10.4 & 87.4 & 72.8 \\
\hline Angola & 29.1 & -6.8 & 93.4 & 83.6 \\
\hline Equatorial Guinea & 63.7 & 17.9 & 119.0 & 92.0 \\
\hline Congo & 77.8 & 27.3 & 131.4 & 86.6 \\
\hline Timor-Leste & 384.0 & 226.4 & 480.8 & 98.2 \\
\hline Sample average (unweighted) & 31.4 & 8.3 & 63.5 & 60.8 \\
\hline Excluding Timor-Leste & 13.7 & -2.7 & 42.6 & 58.9 \\
\hline
\end{tabular}

A fall in oil prices could dramatically worsen overall fiscal positions. Based on a simple adjustment of oil revenue and GDP, keeping ratios of non-oil revenues and total spending to non-oil GDP unchanged, a drop in oil prices to $\$ 60$ per barrel would cause the average overall fiscal surplus of the sample OPCs to fall by over 20 percent of non-oil GDP.

Timor-Leste is the most oil-dependent country among the OPCs and therefore also the most exposed to lower oil prices. The Petroleum Fund has sheltered the budget from large fluctuations in oil prices. However, in 2009, government withdrawals from the Petroleum Fund are for the first time expected to exceed the sustainable spending guideline required to preserve the net present value of oil wealth.

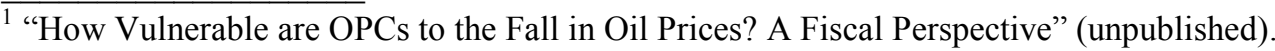




\section{Box 2. Exchange Rate, Competitiveness, and External Sustainability Assessment}

Price competitiveness has weakened and significant structural disincentives to private investment remain.

The nominal effective exchange rate (NEER) has appreciated sharply over the past 12 months, mainly reflecting the depreciation in the Indonesian rupee and the Australian dollar. Relative prices have fallen since mid-2008 along with lower imported food prices, but this was more than offset by the marked NEER appreciation. Thus, the core-CPI-based real effective exchange rate (REER) has moved largely in tandem with the NEER. Steadily low core inflation indicates that price pressures have resulted mainly from global or supply-side factors. However, anecdotal evidence suggests that average wages are high in comparison with Indonesia, the main trading partner, and high public sector pay rates also put pressure on private wages (Figure 4).

Institutional competitiveness has fallen further behind according to global indicators. Surveys have consistently ranked Timor-Leste towards the bottom end of business friendliness and global competitiveness. Since 2007, it dropped another two places on the doing business and global competitiveness score boards.

\section{On current policies, external stability would} be maintained. In 2006-08, current account surpluses were above their long-run sustainable level. Those surpluses largely reflected temporary factors, and in particular the boom in international oil/gas prices. Over the medium run, current account surpluses will decline and converge to the sustainable level.

\footnotetext{
${ }_{1}^{1}$ Computed as the difference between actual oil/gas income and the estimated sustainable income from oil/gas wealth (Box 1).
}

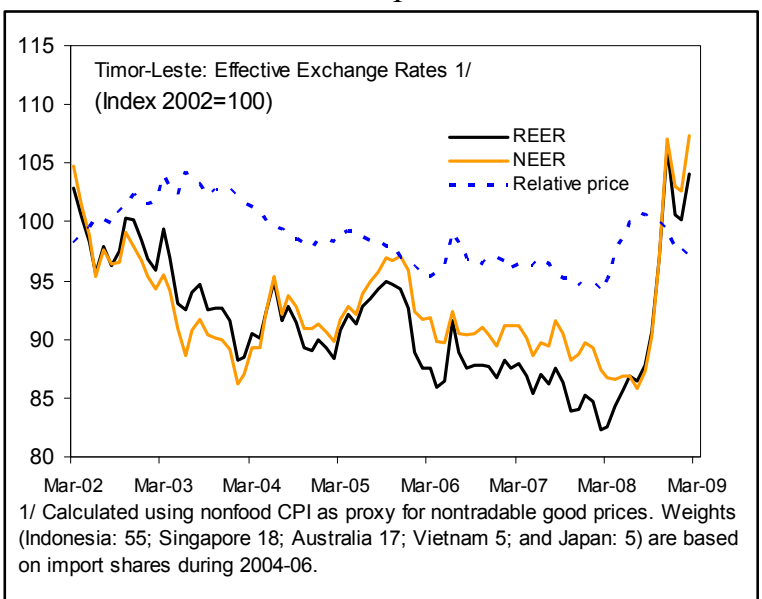

\begin{tabular}{|c|c|c|c|}
\hline \multicolumn{4}{|c|}{ Assessment of Business Climate, 2009} \\
\hline \multicolumn{2}{|c|}{ Doing Business } & \multicolumn{2}{|c|}{ Global Competitiveness Index } \\
\hline Countries & $\begin{array}{r}\text { Rank } \\
\text { among } \\
181\end{array}$ & Countries & $\begin{array}{r}\text { Rank } \\
\text { among } \\
131\end{array}$ \\
\hline Vietnam & 92 & Thailand & 34 \\
\hline Papua New Guinea & 95 & Indonesia & 55 \\
\hline Sri Lanka & 102 & Vietnam & 70 \\
\hline Bangladesh & 110 & Philippines & 71 \\
\hline Nepal & 121 & Sri Lanka & 77 \\
\hline Indonesia & 129 & Cambodia & 109 \\
\hline Cambodia & 135 & Bangladesh & 111 \\
\hline Philippines & 140 & Nepal & 126 \\
\hline Timor-Leste & 170 & Timor-Leste & 129 \\
\hline
\end{tabular}

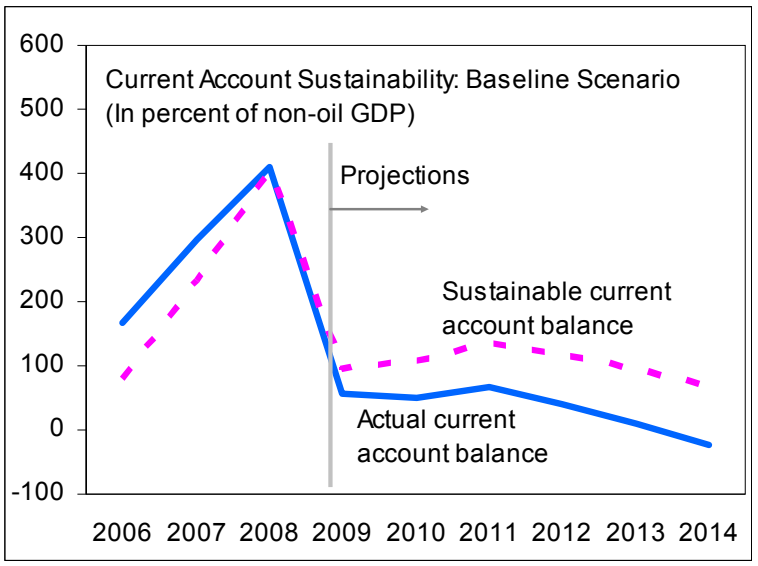




\section{Box 3. Petroleum Fund Performance and Outlook}

According to the Petroleum Fund (PF) Law, all Timor-Leste's income from oil and gas production must go to the PF and withdrawals can only be made to the state budget. Based on the Norwegian model, the PF is invested entirely abroad.

The medium-term evolution of the PF will depend mainly on oil output and prices, and the rate of withdrawals.

- $\quad$ Oil and gas production is expected to stay near current levels for the next several years but revenue is highly sensitive to prices (with some lag). From current levels, a $\$ 10 /$ barrel fall in the price of crude oil reduces Timorese government receipts by about 25 percent.

- In principle, withdrawals should be guided by the estimated sustainable income (ESI), defined under the PF Law as 3 percent of the total petroleum wealth (the current $\mathrm{PF}$ balance plus the net present value of future oil/gas receipts). Actual withdrawals can be higher, as long as the Government provides Parliament with a detailed explanation of why it is in the longterm interest of the country. Reflecting higher oil prices, ESI has increased substantially since the

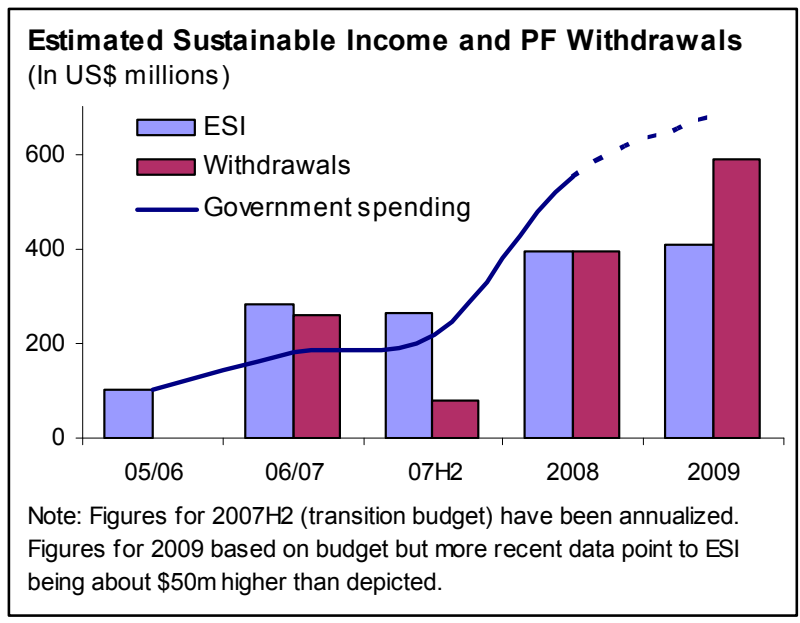
first estimate for FY2005/06 and withdrawals have so far remained within the limit. With spending continuing to increase, however, this year is likely to be the first where withdrawals exceed ESI. 


\section{Box 4. Outlook for Oil/Gas Production}

Timor-Leste at present has only one producing field, Bayu-Undan, located in an off-shore area (JPDA) subject to revenue-sharing with Australia. Based on conservative estimates, official projections have production levels from this field gradually tapering off before coming to an end by 2023. Remaining revenue to Timor-Leste is estimated at $\$ 11$ billion in net present value.

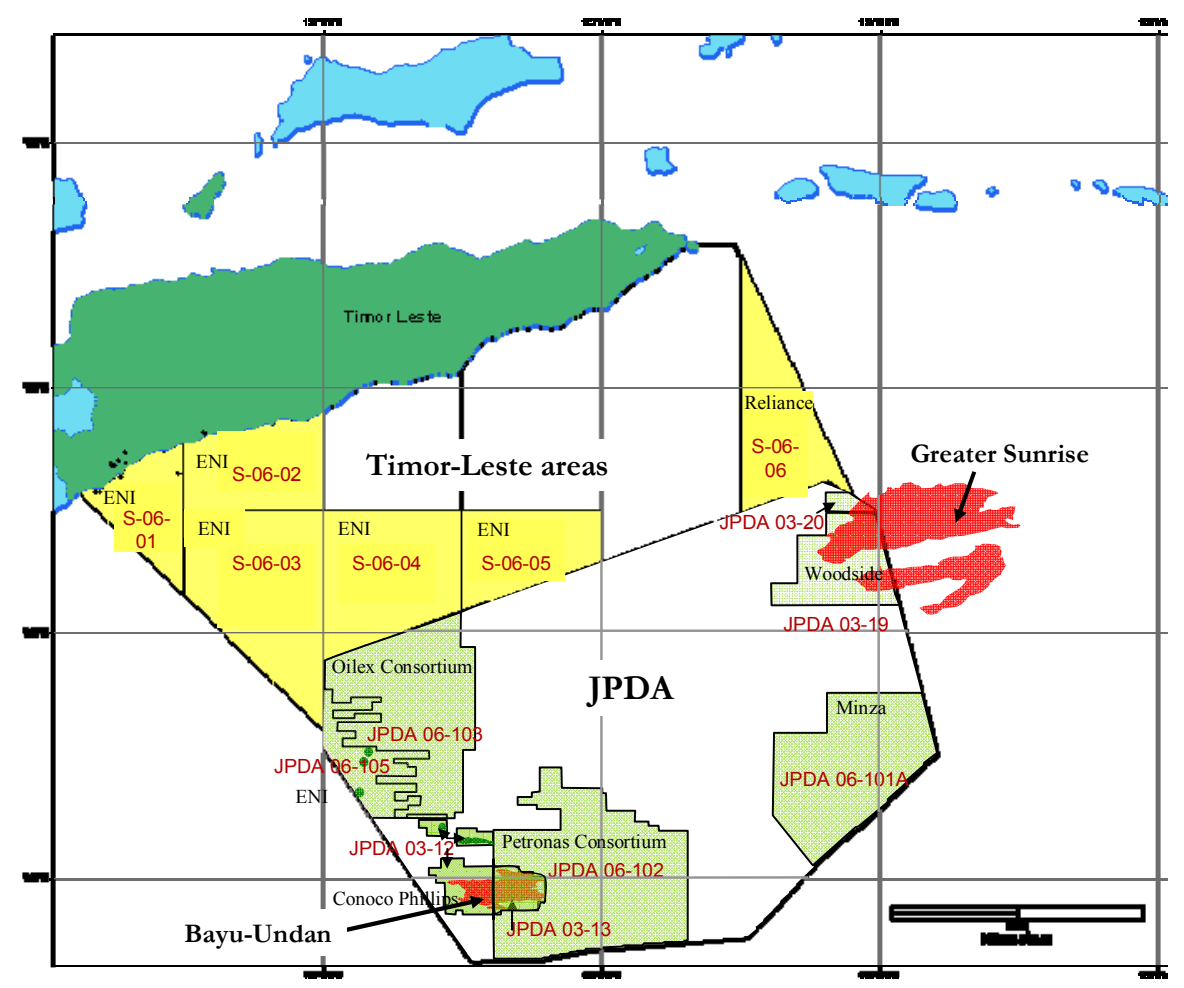

The Greater Sunrise project could potentially generate income of a magnitude close to that remaining from Bayu-Undan. A development plan has yet to be agreed, however, and significant revenue would take almost a decade to materialize. Kitan, a more recent discovery, could come into production already by 2011 but is only about 5 percent the size of Bayu-Undan. More fields could still be discovered but there is considerable uncertainty.

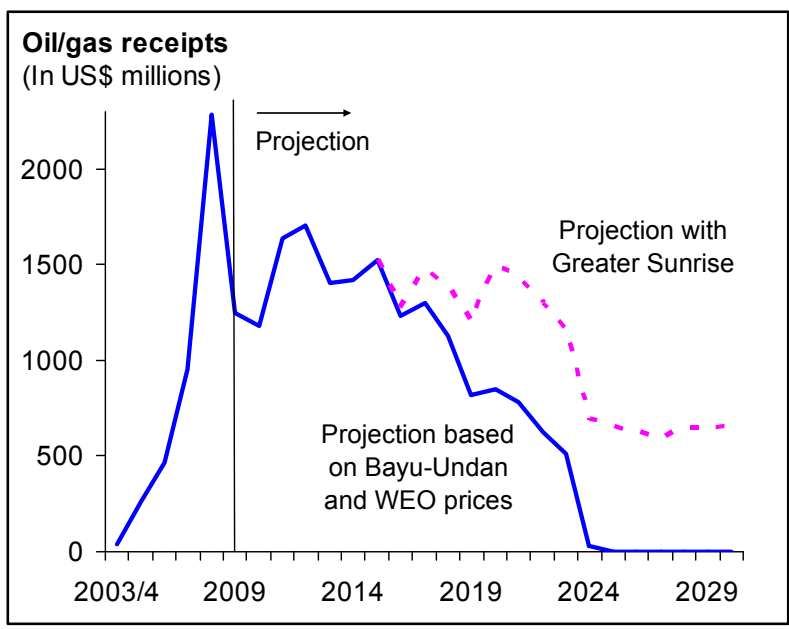




\section{Box 5. Timor-Leste's Petroleum Fiscal Regimes}

A complex set of fiscal regimes presents major challenges in both implementation and administration. Timor-Leste has no final maritime boundary in the Timor Sea, but has three interlocking treaties with Australia covering the Joint Petroleum Development Area (JPDA) and the overlapping Sunrise unit area. A combination of production sharing and taxation generates revenue for Timor-Leste. The treaty architecture defines different production-sharing contract regimes and taxation regimes, covering Bayu-Undan, the Sunrise fields, the remainder of the JPDA, and areas of exclusive jurisdiction.

The IMF's Fiscal Affairs Department recently provided technical assistance on the administration and implementation of petroleum fiscal regimes. It was found that the fiscal regimes have generally been implemented and administered well, but continued efforts are needed to maximize benefits from future petroleum operations. 
Figure 1. Timor-Leste: Regional and Global Comparisons 1/

Timor Leste's living standards remain among the lowest in the developing world.
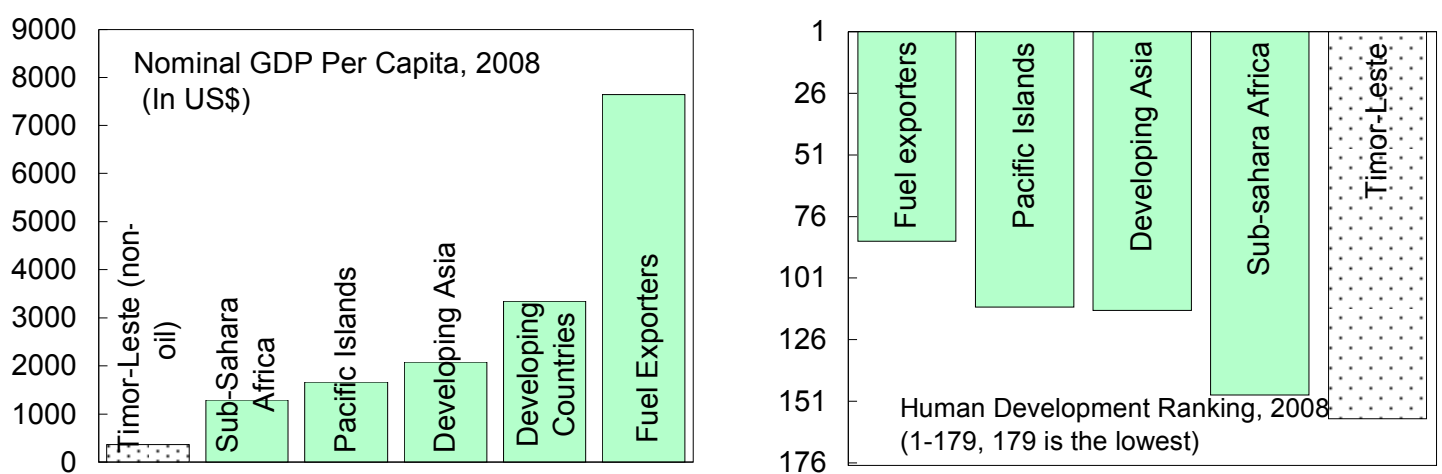

However, if the good macroeconomic policies so far are maintained, with low inflation and no public or external debt,...
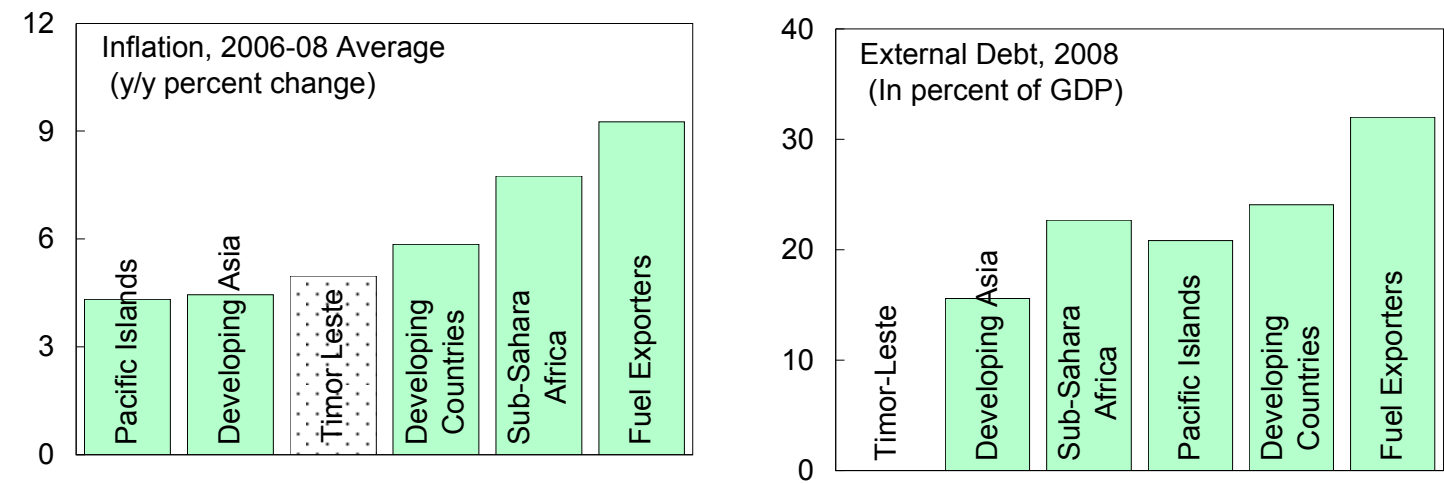

....and the considerable oil wealth is effectively and sustainably harnessed, there is significant scope for promoting non-oil growth.2/
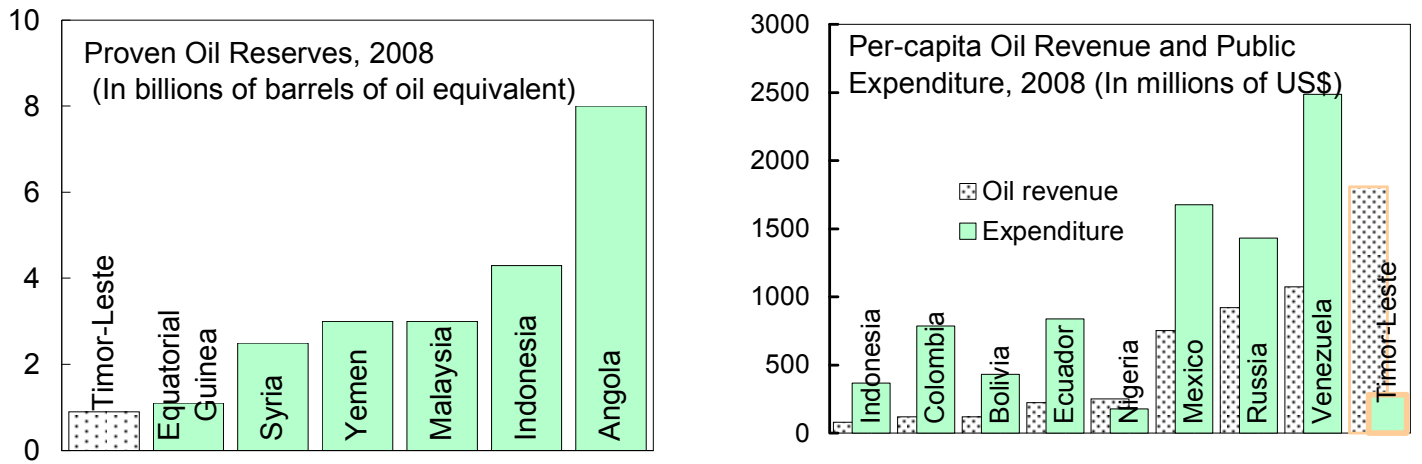

Sources: Authorities; UN, Human Development Indicators, 2008/09; IMF, World Economic Outlook and FAD-DEME databases; PennWell Corporation, Oil \& Gas Journal, December, 2008; and Fund staff estimates.

1/ For Timor-Leste, calculations in non-oil GDP.

2/ Bayu Undan field only. 
Figure 2. Timor Leste: Recent Macroeconomic Developments

Rapidly rising public spending has fueled high non-oil growth in the last two years. Inflation rose in 2008 along with food prices, but has now abated.
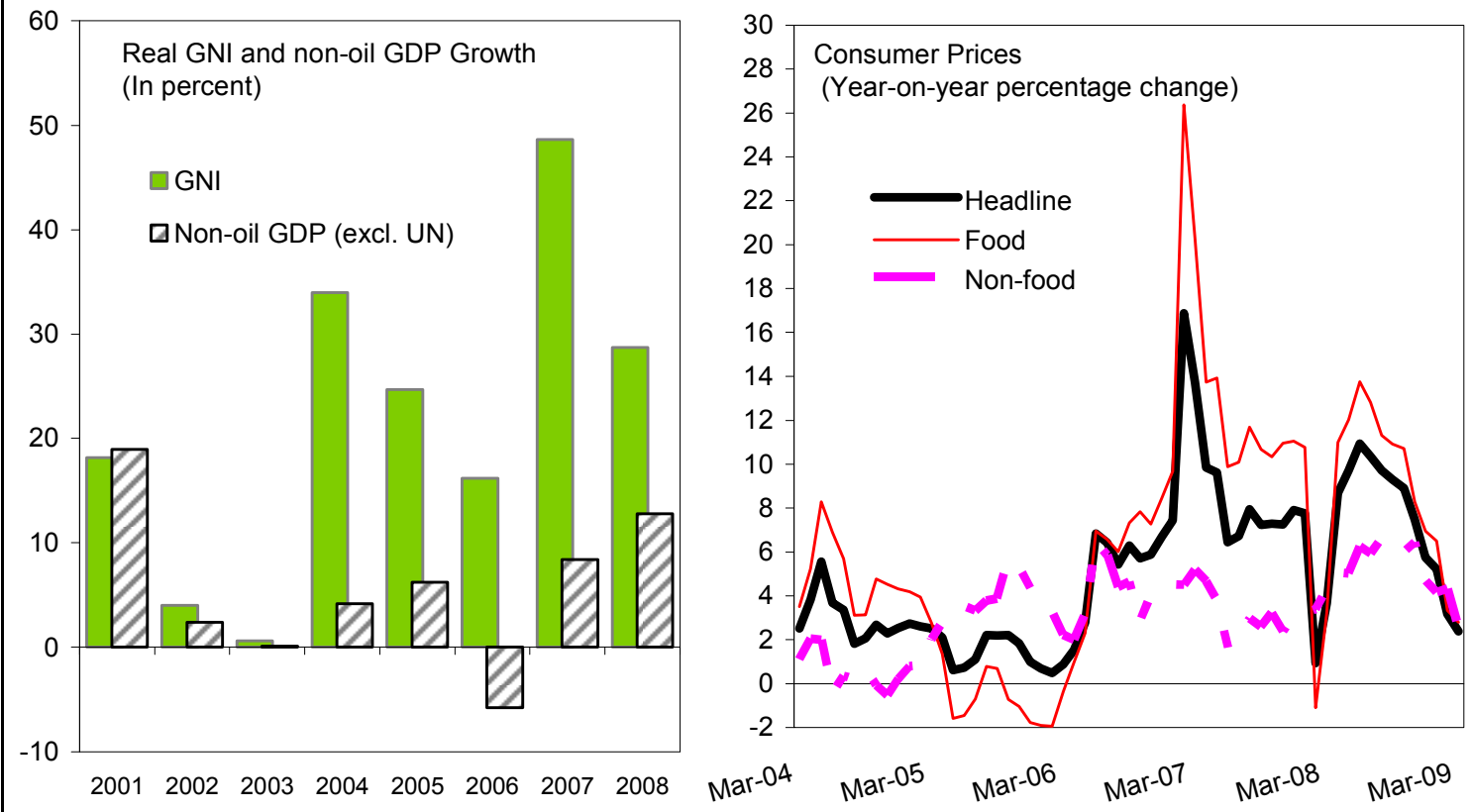

Growing oil/gas revenue has boosted national income and the current account surplus. Non-oil exports have grown but remain very small.
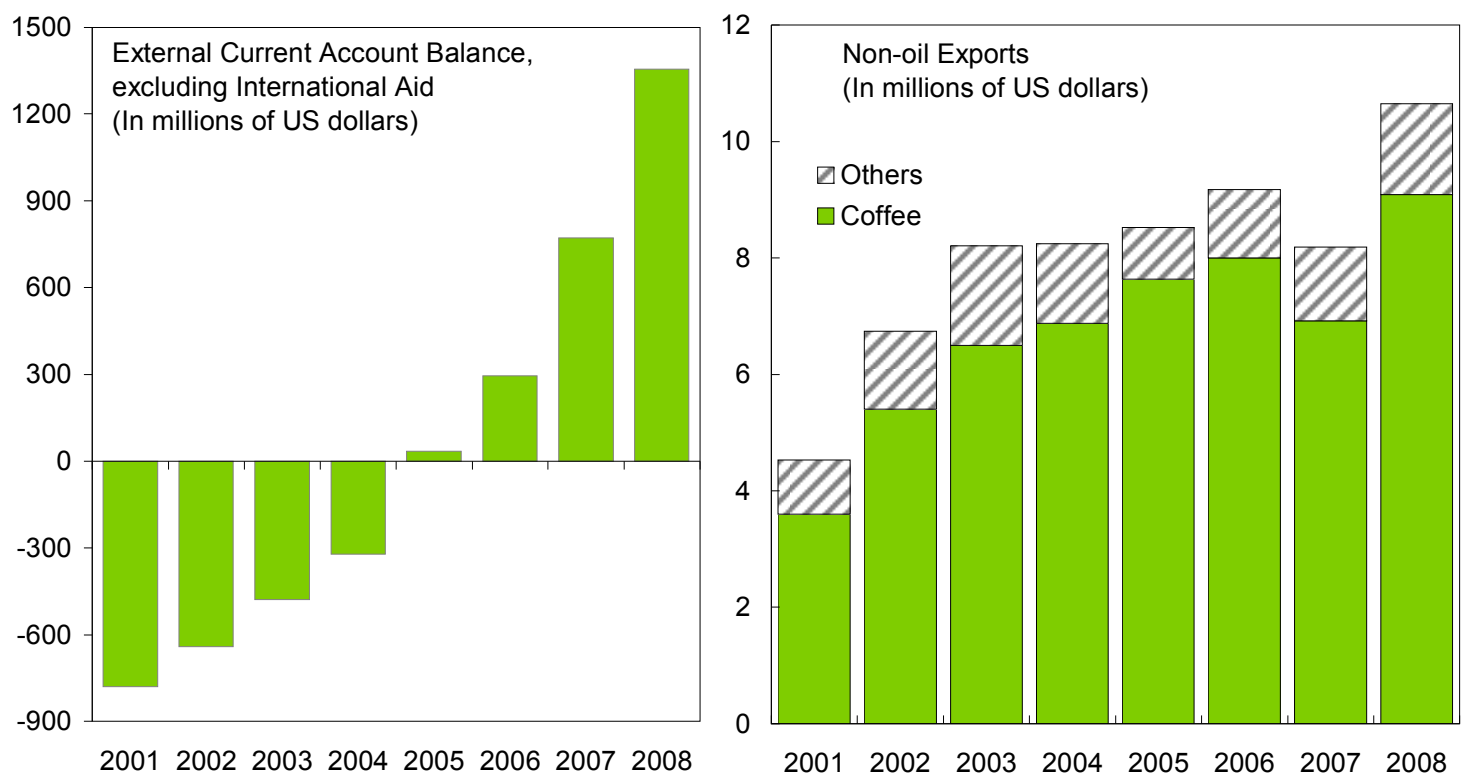

Sources: Timor-Leste authorities; and Fund staff estimates and projections. 


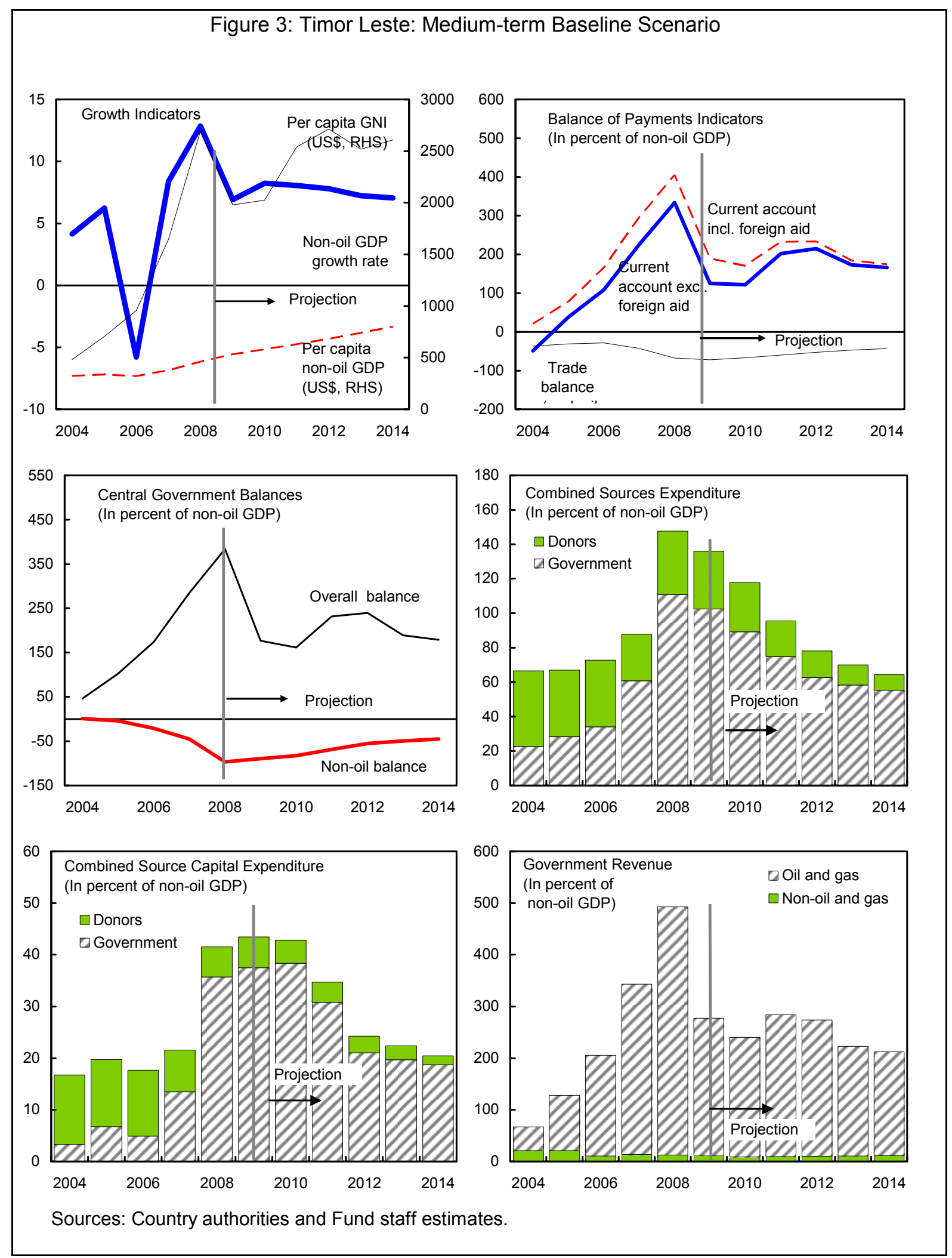

CInternational Monetary Fund. Not for Redistribution 
Figure 4. Timor-Leste: Developments in government wages and salaries

Wages and salaries have increased rapidly as government employment has grown...
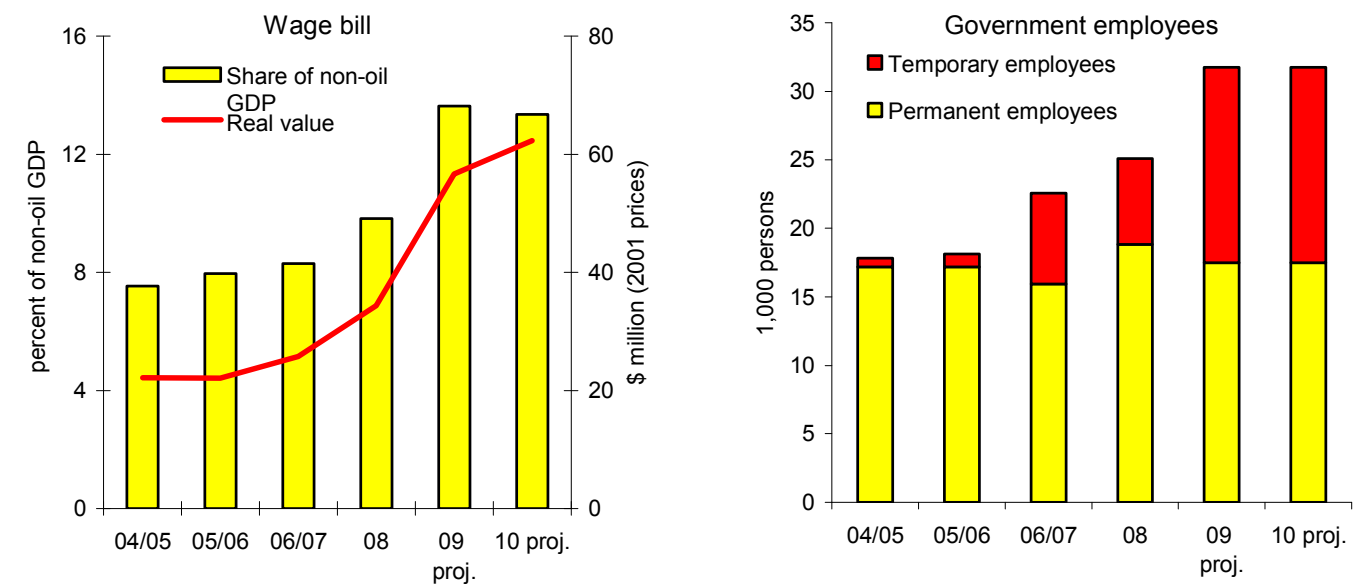

...and government pay rates have risen.
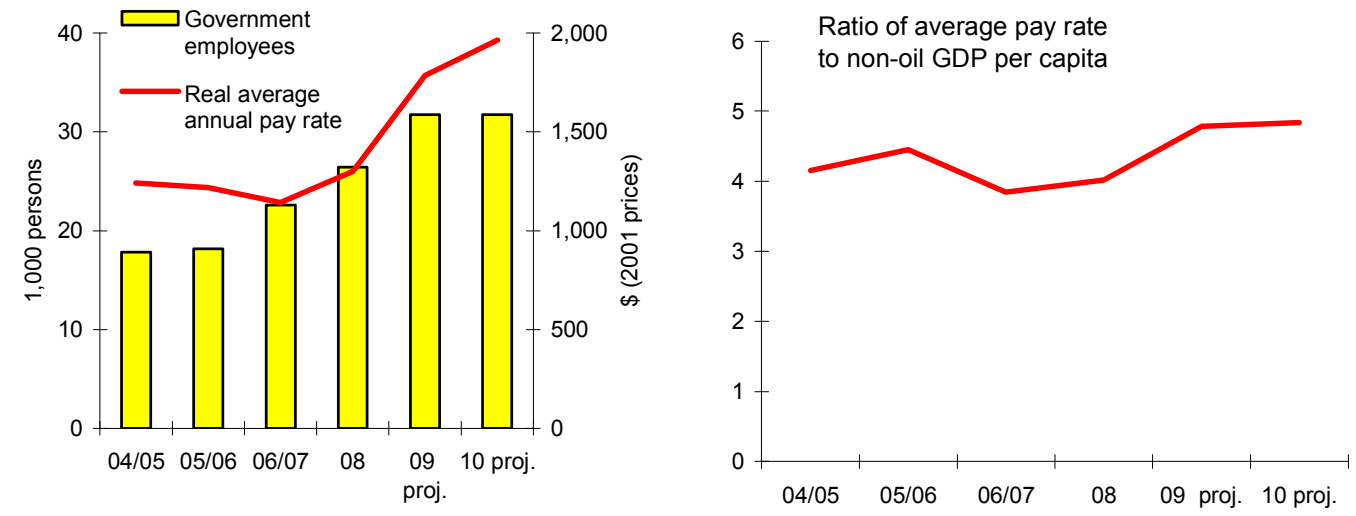

The wage bill is now high by regional standards, reflecting high levels of employment and average pay rates (relative to GDP per capita).
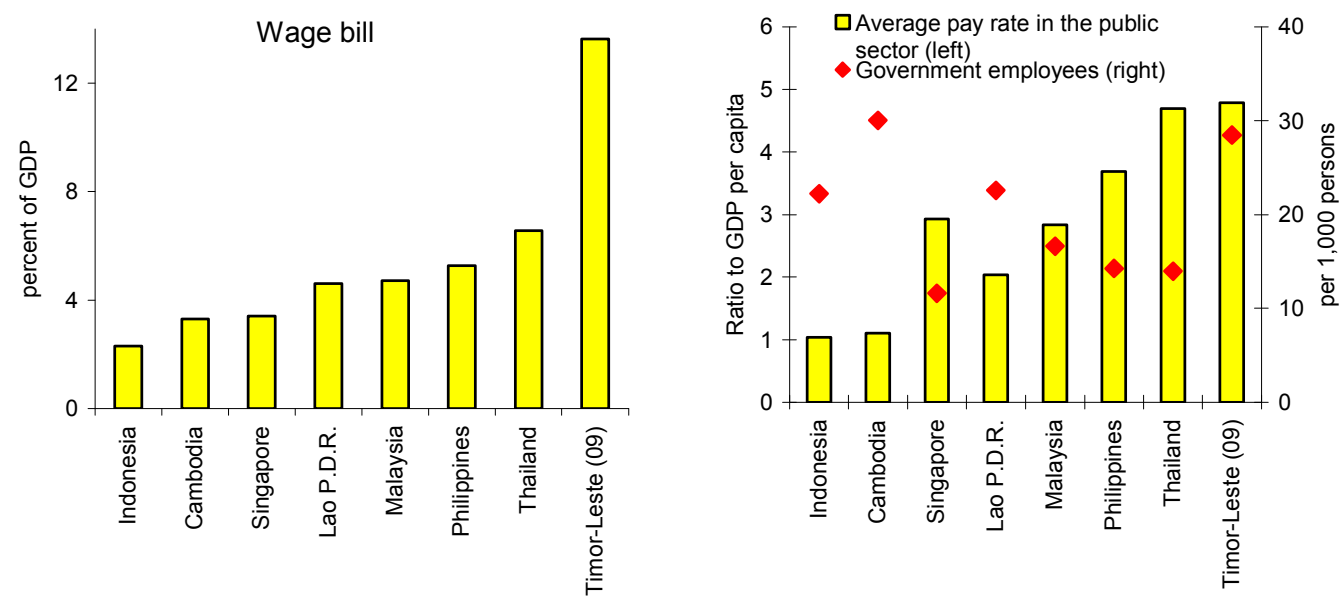

Sources: Timor-Leste Ministry of Finance. General Budget of the State, budget execution reports for various years; staff estimates; staff reports; IMF Government Finance Statistics; World Bank. Administrative and civil service reform dataset. Note: 1. Non-oil GDP is used in calculation for Timor-Leste.

2. Average pay rate is found as government wages and salaries (cash basis) divided by the total number of civil servants, non-civil servants and employees of autonomous agencies.

3. Data for other countries are latest available estimates. 
Table 1. Timor-Leste: Selected Social Indicators 1/

\begin{tabular}{|c|c|c|c|}
\hline & $\begin{array}{l}\text { Timor- } \\
\text { Leste }\end{array}$ & $\begin{array}{c}\text { East Asia } \\
\text { and Pacific } \\
\text { Island } \\
\text { countries }\end{array}$ & $\begin{array}{l}\text { Low } \\
\text { income } \\
\text { countries }\end{array}$ \\
\hline Gross national income per capita (US\$) 2/ & 1650 & 2,180 & 578 \\
\hline GDP per capita (PPP, current US\$) & 776 & 4,939 & 1,530 \\
\hline \multicolumn{4}{|l|}{ Demography } \\
\hline Total population (in millions) & 1.0 & 1,914 & 1,296 \\
\hline Population growth (in percent) $3 /$ & 3.2 & 0.9 & 2.3 \\
\hline \multicolumn{4}{|l|}{ Life expectancy and mortality $4 /$} \\
\hline Life expectancy at birth (years) & 59 & 71 & 57 \\
\hline Male & 58 & 69 & 56 \\
\hline Female & 60 & 73 & 58 \\
\hline Infant mortality (per thousand live births) & 52 & 24 & 85 \\
\hline Under 5 mortality rate (per thousand live births) & 61 & 29 & 135 \\
\hline \multicolumn{4}{|l|}{ Education (in percent) } \\
\hline Literacy rate $5 /$ & 47 & 91 & 61 \\
\hline Male & 56 & 95 & 72 \\
\hline Female & 39 & 87 & 50 \\
\hline Gross primary school enrollment rate & 107 & 110 & 94 \\
\hline \multicolumn{4}{|l|}{ Health } \\
\hline \multicolumn{4}{|c|}{ Immunization rate (in percent of children less than 5 years old) } \\
\hline Measles & 57 & $894 /$ & $764 /$ \\
\hline DPT & 68 & $894 /$ & $774 /$ \\
\hline \multicolumn{4}{|l|}{ Other indicators (in percent) } \\
\hline The population below the poverty line & 50 & $\ldots$ & $\ldots$ \\
\hline Households with access to electricity & 36 & $\ldots$ & $\ldots$ \\
\hline Population with access to improved water source & 65 & $874 /$ & 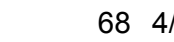 \\
\hline
\end{tabular}

Sources: World Bank, World Development Indicators; and Country authorities.

1/ Data are for 2007, unless otherwise indicated.

2/ For comparators, GNI is calculated using Atlas method.

3/ Average growth over 2000-07.

4/ Figures are for 2006.

5/ For Timor-Leste, ability to read and write a letter without difficulty among population above age 18 . 
Table 2: Timor-Leste: Selected Social and Economic Indicators

I. Social and Demographic Indicators

Income (2007)

GNI per capita (in U.S. dollars)

Non-oil GDP per capita (in U.S. dollars)

Population characteristics (2006)

Total population (in millions)

Population growth (in percent)

Life expectancy at birth (years)

1,650
379

1.015
3.2
59

1,650
379

3.2

59
Education and health (2007)

Literacy rate (in percent)

Infant mortality rate (per 1000 births)

47.3

Poverty and access to services (2007)

Poverty rate (in percent)

Access to improved water (in percent)

Access to electricity (in percent)

49.9

64.7

36.1

II. Economic Indicators

\begin{tabular}{|c|c|c|c|c|c|c|c|}
\hline & 2004 & 2005 & 2006 & 2007 & $\begin{array}{c}2008 \\
\text { Prel. }\end{array}$ & $\begin{array}{l}2009 \\
\text { Proj. }\end{array}$ & $\begin{array}{c}2010 \\
\text { Proj. }\end{array}$ \\
\hline \multicolumn{8}{|l|}{ Output and prices } \\
\hline GNI at current prices (US\$ million) & 460 & 695 & 972 & 1,728 & 2,915 & 2,198 & 2,312 \\
\hline Non-oil GDP at current prices (US\$ million) & 309 & 332 & 327 & 398 & 499 & 590 & 659 \\
\hline Real non-oil GDP growth (percentage change) & 4.2 & 6.2 & -5.8 & 8.4 & 12.8 & 7.4 & 7.5 \\
\hline Including United Nations $1 /$ & 0.4 & 2.3 & -3.4 & 16.8 & 12.2 & 8.0 & 2.0 \\
\hline Inflation (CPI, percentage change, end-period) & 2.5 & 1.0 & 6.7 & 7.6 & 6.1 & 2.3 & 4.0 \\
\hline Inflation (CPI, percentage change, period average) & 3.2 & 1.8 & 4.1 & 8.9 & 7.6 & 1.3 & 4.0 \\
\hline & \multicolumn{7}{|c|}{ (in percent of non-oil GDP) } \\
\hline \multicolumn{8}{|l|}{ Savings and investment } \\
\hline Gross investment 2/ & 21 & 21 & 23 & 26 & 46 & 51 & 54 \\
\hline Gross national savings & 42 & 99 & 188 & 322 & 451 & 242 & 225 \\
\hline External savings & -21 & -78 & -165 & -296 & -405 & -191 & -171 \\
\hline \multicolumn{8}{|l|}{ Central government finances } \\
\hline Revenues & 67 & 128 & 205 & 343 & 490 & 279 & 257 \\
\hline Domestic revenues & 10 & 11 & 10 & 11 & 9 & 10 & 9 \\
\hline Petroleum revenue & 46 & 107 & 195 & 330 & 481 & 269 & 248 \\
\hline Grants & 11 & 10 & 0 & 3 & 0 & 0 & 0 \\
\hline Expenditure (cash basis) & 20 & 26 & 32 & 59 & 106 & 101 & 94 \\
\hline Recurrent expenditure & 17 & 19 & 27 & 46 & 70 & 63 & 53 \\
\hline Capital expenditure & 3 & 7 & 5 & 13 & 36 & 38 & 41 \\
\hline Overall balance & 46 & 102 & 174 & 284 & 384 & 178 & 162 \\
\hline Non-oil fiscal balance & 1 & -5 & -21 & -46 & -97 & -91 & -85 \\
\hline \multicolumn{8}{|l|}{ Combined sources fiscal operations $3 /$} \\
\hline Domestic revenue and budget grants & 23 & 24 & 13 & 15 & 11 & 12 & 11 \\
\hline Expenditure & 66 & 67 & 73 & 88 & 144 & 136 & 126 \\
\hline Recurrent expenditure & 50 & 47 & 55 & 66 & 103 & 92 & 80 \\
\hline Capital expenditure & 17 & 20 & 18 & 22 & 41 & 44 & 47 \\
\hline Overall balance & -43 & -43 & -60 & -73 & -134 & -125 & -115 \\
\hline \multicolumn{8}{|l|}{ Money and credit } \\
\hline Broad money (end-period) 4/ & 21 & 23 & 31 & 36 & 39 & $\ldots$ & $\ldots$ \\
\hline Net domestic assets (end-period) & -38 & -24 & -3 & -43 & -37 & $\ldots$ & $\ldots$ \\
\hline
\end{tabular}

\section{External sector}

Current account

Merchandise exports 2/

Merchandise imports

(in millions of U.S. dollars, unless otherwise indicated)

Memorandum items:

Donor development assistance (\% of non-oil GDP)

Crude oil price (\$ per barrel) $5 /$

Oil/gas receipts

Petroleum Fund withdrawals

Petroleum Fund balance (end-period) 6/

260
8

8
112

101

7
176

2,021

1,127

1,127

122

$176-353$

440

469

Petroleum Fund balance (percent of non-oil GDP) 6

$\begin{array}{rr}55 & 4 \\ 38 & 53 \\ 141 & 349 \\ \text { n.a. } & \\ 14 & 37 \\ 5 & 11\end{array}$

$\begin{array}{rrrrrr}49 & 39 & 30 & 37 & 34 & 30 \\ 53 & 64 & 71 & 97 & 61 & 75 \\ 349 & 612 & 1,258 & 2,284 & 1,498 & 1,511 \\ 0 & 0 & -300 & -396 & -589 & -494 \\ 370 & 1,012 & 2,086 & 4,197 & 5,109 & 6,197 \\ 112 & 310 & 525 & 841 & 866 & 940\end{array}$

Sources: Data provided by the Timor-Leste authorities; and Fund staff estimates.

1/ Includes locally paid compensation of UN peacekeeping mission staff.

2/ Excludes oil/gas sector.

3/ Includes autonomous agencies and quasi-fiscal expenditure by donors outside the central government budget. The revenue decline in

2005 reflects the creation of the Petroleum Fund to which all oil revenue now accrues. Income from the fund and donor assistance finances the deficit.

4/ Excludes currency holdings by the public, for which no data are available.

5/ Simple average of three spot prices; Dated Brent, West Texas Intermediate, and the Dubai Fateh.

6/ Figure for 2004 refers to the Timor-Sea account, which preceded the August 2005 establishment of the Petroleum Fund. 
Table 3. Timor-Leste: Central Government Budget FY2004/05-2010 1/

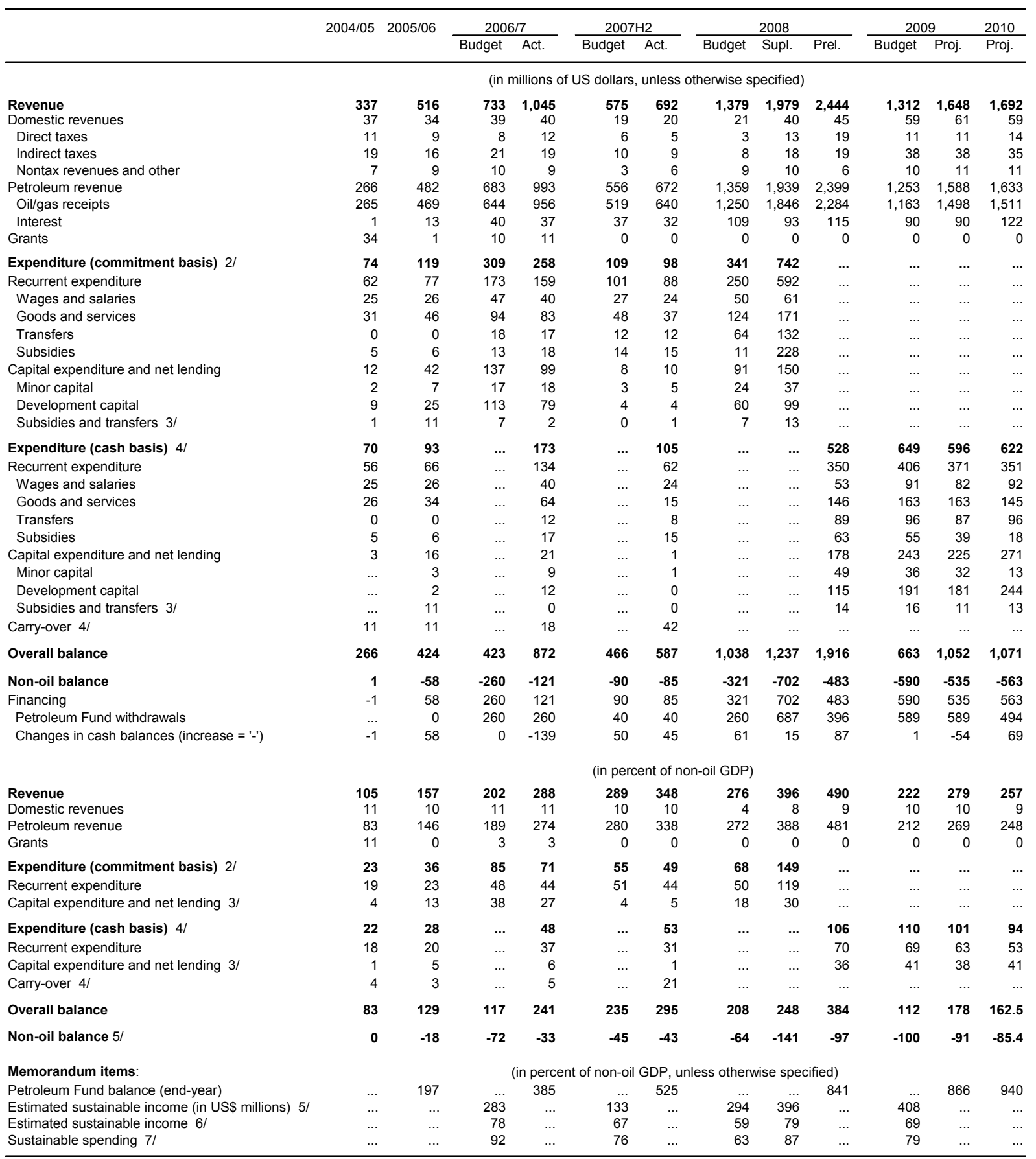

Sources: Timor-Leste authorities; and Fund staff estimates.

1/ Fiscal year: July-June until June 2007; calendar year starting 2008. Central Government includes subsidies to Autonomous Agencies. Revenue from government rice sales (estimated at $\$ 17$ million in 2008 and $\$ 10$ million in 2009) is excluded and only the net subsidy included in recurrent expenditure.

2/ The budget moved toward a cash basis in 2008 and the authorities stopped reporting commitments. Of the $\$ 528$ million reported as spent in 2008 ,

an estimated $\$ 80$ million was actually paid out in 2009 , with spending under the 2008 budget allowed to continue in early 2009 as a transitional measure before fully applying cash-based principles.

3/ Includes allocations for BPA capitalization (\$10.5 million in 2006/07).

4/ Cash expenditure includes carry-over expenditure from previous years (the reporting of which was not disaggregated prior to 2008).

$5 /$ Defined as overall balance minus petroleum revenue.

6/ Permanent income from oil and gas, estimated according to the Petroleum Fund law for each budget.

7/ Adds non-petroleum revenue to estimated sustainable income from petroleum. 
Table 4. Timor Leste: Combined Sources Budget 2004 - 2010

\begin{tabular}{|c|c|c|c|c|c|c|c|}
\hline & 2004 & 2005 & 2006 & 2007 & 2008 & $\begin{array}{l}2009 \\
\text { Proj. }\end{array}$ & $\begin{array}{l}2010 \\
\text { Proj. }\end{array}$ \\
\hline & \multicolumn{7}{|c|}{ (in millions of U.S. dollars) } \\
\hline Revenue & 72 & 79 & 42 & 60 & 53 & 68 & 73 \\
\hline Domestic revenue 1/ & 30 & 37 & 34 & 42 & 45 & 61 & 59 \\
\hline Direct taxes & 7 & 11 & 10 & 13 & 19 & 11 & 14 \\
\hline Indirect taxes & 19 & 17 & 17 & 19 & 19 & 38 & 35 \\
\hline Nontax revenues and other & 5 & 9 & 7 & 11 & 6 & 11 & 11 \\
\hline Autonomous agencies own revenue & 7 & 8 & 7 & 7 & 8 & 8 & 14 \\
\hline Grant financing (budget support) & 35 & 33 & 1 & 11 & 0 & 0 & 0 \\
\hline Expenditure (cash basis) & 205 & 222 & 238 & 349 & 720 & 804 & 833 \\
\hline Recurrent expenditure & 154 & 157 & 180 & 263 & 513 & 544 & 525 \\
\hline Central government and autonomous agencies & 60 & 71 & 95 & 188 & 358 & 379 & 365 \\
\hline Donor projects $2 /$ & 94 & 86 & 85 & 75 & 155 & 165 & 160 \\
\hline Capital expenditure & 52 & 66 & 58 & 86 & 207 & 260 & 307 \\
\hline Central government and autonomous agencies & 10 & 22 & 16 & 53 & 178 & 225 & 271 \\
\hline Donor projects $2 /$ & 41 & 43 & 42 & 32 & 29 & 36 & 37 \\
\hline Overall balance & -133 & -144 & -196 & -289 & -667 & -736 & -759 \\
\hline Financing & 133 & 144 & 196 & 289 & 667 & 736 & 759 \\
\hline Oil fund financing of central govt. non-oil fiscal deficit & 137 & -4 & 0 & 300 & 396 & 589 & 494 \\
\hline Project financing by donors $3 /$ & 135 & 129 & 126 & 107 & 184 & 201 & 107 \\
\hline \multirow[t]{2}{*}{ Change in cash balances (increase -) } & -122 & 21 & 62 & -126 & 87 & -54 & 69 \\
\hline & \multicolumn{7}{|c|}{ (in percent of non-oil GDP) } \\
\hline Revenue & 23 & 24 & 13 & 15 & 11 & 12 & 11 \\
\hline Domestic revenue $1 /$ & 10 & 11 & 10 & 11 & 9 & 10 & 9 \\
\hline Autonomous agencies own revenue & 2 & 2 & 2 & 2 & 2 & 1 & 2 \\
\hline Grant financing (budget support) & 11 & 10 & 0 & 3 & 0 & 0 & 0 \\
\hline Expenditure (cash basis) 2/ & 66 & 67 & 73 & 88 & 144 & 136 & 126 \\
\hline Recurrent expenditure & 50 & 47 & 55 & 66 & 103 & 92 & 80 \\
\hline Capital expenditure & 17 & 20 & 18 & 22 & 41 & 44 & 47 \\
\hline Overall Balance & -43 & -43 & -60 & -73 & -134 & -125 & -115 \\
\hline Financing & 43 & 43 & 60 & 73 & 134 & 125 & 115 \\
\hline Oil fund financing of central govt. non-oil fiscal deficit & 44 & -1 & 0 & 75 & 79 & 100 & 75 \\
\hline Project financing by donors & 44 & 39 & 39 & 27 & 37 & 34 & 16 \\
\hline Change in cash balances (increase -) & -39 & 6 & 19 & -32 & 18 & -9 & 10 \\
\hline
\end{tabular}

Sources: Timor-Leste authorities; and Fund staff estimates.

1/ Oil/gas revenue is not included as a budget revenue item and flows directly to the petroleum fund. The amount necessary to cover the non-oil fiscal deficit is withdrawn from the fund and transferred to the budget and recorded as a financing item.

2/ Includes sector projects which the government has identified as necessary to achieve development objectives, but may not be wholly funded by the government.

3/ Donor grants excluding budget support. 
Table 5. Timor-Leste: Balance of Payments 2004-2010

\begin{tabular}{|c|c|c|c|c|c|c|c|}
\hline & 2004 & 2005 & 2006 & 2007 & 2008 & $\begin{array}{c}2009 \\
\text { Proj. }\end{array}$ & $\begin{array}{l}2010 \\
\text { Proj. }\end{array}$ \\
\hline & \multicolumn{7}{|c|}{ (In millions of U.S. dollars) } \\
\hline Current account & 64 & 260 & 540 & 1,177 & 2,021 & 1,127 & 1,127 \\
\hline Trade balance & -115 & -104 & -91 & -169 & -339 & -431 & -457 \\
\hline Exports of goods $1 /$ & 8 & 8 & 9 & 7 & 14 & 10 & 13 \\
\hline Of which: Coffee & 7 & 8 & 9 & 6 & 12 & 7 & 9 \\
\hline Imports of goods & 122 & 112 & 101 & 176 & 353 & 440 & 469 \\
\hline Services (net) & -187 & -131 & -199 & -263 & -407 & -437 & -385 \\
\hline Exports & 47 & 37 & 34 & 63 & 61 & 87 & 80 \\
\hline Of which: Travel & 19 & 21 & 20 & 26 & 25 & 27 & 30 \\
\hline Imports & 234 & 168 & 233 & 325 & 468 & 524 & 465 \\
\hline Of which: UN and donor related & 201 & 137 & 204 & 286 & 369 & 403 & 334 \\
\hline Income (net) & 151 & 363 & 645 & 1,331 & 2,415 & 1,608 & 1,653 \\
\hline Of which: Oil/gas receipts and interest & 141 & 354 & 637 & 1,312 & 2,399 & 1,588 & 1,633 \\
\hline Current transfers (net) & 215 & 133 & 185 & 278 & 351 & 386 & 316 \\
\hline Of which: International assistance & 215 & 133 & 184 & 281 & 355 & 386 & 315 \\
\hline Capital and financial accounts & 57 & -289 & -609 & $-1,031$ & $-2,041$ & $-1,080$ & $-1,196$ \\
\hline Official capital transfers & 41 & 43 & 42 & 32 & 29 & 36 & 37 \\
\hline Financial account $2 /$ & 15 & -332 & -651 & $-1,063$ & $-2,070$ & $-1,116$ & $-1,233$ \\
\hline Of which: Oil/gas savings & -3 & -358 & -637 & $-1,012$ & $-2,003$ & -999 & $-1,140$ \\
\hline Overall balance & 121 & -29 & -70 & 147 & -20 & 47 & -69 \\
\hline \multirow[t]{2}{*}{ Changes in foreign assets (increase -) } & -121 & 29 & 70 & -147 & 20 & -47 & 69 \\
\hline & \multicolumn{7}{|c|}{ (In percent of non-oil GDP) } \\
\hline Current account & 21 & 78 & 165 & 296 & 405 & 191 & 171 \\
\hline Trade balance & -37 & -31 & -28 & -43 & -68 & -73 & -69 \\
\hline Services (net) & -60 & -39 & -61 & -66 & -81 & -74 & -58 \\
\hline Income (net) & 49 & 109 & 197 & 335 & 484 & 272 & 251 \\
\hline Current transfers (net) & 70 & 40 & 57 & 70 & 70 & 65 & 48 \\
\hline Capital and financial accounts & 18 & -87 & -186 & -259 & -409 & -183 & -181 \\
\hline \multirow[t]{2}{*}{ Overall balance } & 39 & -9 & -21 & 37 & -4 & 8 & -10 \\
\hline & \multicolumn{7}{|c|}{ (In millions of U.S. dollars) } \\
\hline Memorandum item: & & & & & & & \\
\hline Public foreign assets (end-period) & 135 & 524 & 1,096 & 2,316 & 4,407 & 5,367 & 6,385 \\
\hline
\end{tabular}

Sources: Data provided by the Timor-Leste authorities, and Fund staff estimates.

1/ Excludes oil/gas receipts, which are recorded under the income account because of lack of detailed data on the oil/gas sector (including production, exports, service payments, and profit remittances).

2/ Includes errors and omissions. 
Table 6. Timor-Leste: Monetary Developments, 2004-2008

\begin{tabular}{|c|c|c|c|c|c|}
\hline & 2004 & 2005 & 2006 & 2007 & 2008 \\
\hline & \multicolumn{5}{|c|}{ (in millions of U.S. dollars) } \\
\hline \multicolumn{6}{|l|}{ Banking System } \\
\hline Net foreign assets & 184 & 159 & 113 & 318 & 393 \\
\hline Assets $1 /$ & 227 & 206 & 144 & 356 & 422 \\
\hline Gross reserves & 182 & 153 & 84 & 230 & 210 \\
\hline Liabilities & 43 & 47 & 31 & 38 & 29 \\
\hline Net domestic assets & -116 & -80 & -11 & -172 & -187 \\
\hline Claims on government (net) & -187 & -151 & -83 & -219 & -230 \\
\hline Claims on private sector & 88 & 106 & 111 & 101 & 102 \\
\hline Other ("net other assets") & 0 & 0 & 0 & 0 & 0 \\
\hline Other items, net (incl capital account) & -18 & -35 & -40 & -54 & -60 \\
\hline Broad money 2/ & 66 & 78 & 100 & 144 & 193 \\
\hline Narrow money & 32 & 39 & 54 & 75 & 104 \\
\hline Currency in circulation & 1 & 2 & 2 & 2 & 2 \\
\hline Demand deposits & 31 & 38 & 52 & 73 & 102 \\
\hline Other deposits & 34 & 38 & 46 & 68 & 88 \\
\hline Non-liquid liabilities & 2 & 1 & 2 & 2 & 13 \\
\hline \multicolumn{6}{|l|}{ Banking and Payments Authority (central bank) } \\
\hline Net foreign assets $1 /$ & 182 & 153 & 84 & 230 & 210 \\
\hline Assets & 182 & 153 & 84 & 230 & 210 \\
\hline Gross reserves & 182 & 153 & 84 & 230 & 210 \\
\hline Others & 0 & 0 & 0 & 0 & 0 \\
\hline Liabilities & 0 & 0 & 0 & 0 & 0 \\
\hline Net domestic assets & -175 & -147 & -74 & -210 & -173 \\
\hline Central Government (net position) & -169 & -129 & -56 & -190 & -196 \\
\hline Claims on domestic banks and other claims & -8 & -19 & -19 & -20 & 22 \\
\hline Other items, net & 1 & 1 & 1 & 1 & 1 \\
\hline Liabilities & 7 & 6 & 9 & 21 & 37 \\
\hline Currency in circulation 2/ & 1 & 2 & 2 & 2 & 2 \\
\hline Financial institutions & 5 & 5 & 6 & 18 & 23 \\
\hline Other deposits and liquid liabilities & 0 & 0 & 0 & 0 & 0 \\
\hline Non-liquid liabilities & 1 & 0 & 1 & 0 & 12 \\
\hline \multicolumn{6}{|l|}{ Commercial banks $3 /$} \\
\hline Net foreign assets & 1 & 6 & 29 & 88 & 182 \\
\hline Assets & 44 & 52 & 61 & 126 & 211 \\
\hline Liabilities & 43 & 47 & 31 & 38 & 29 \\
\hline Net domestic assets & 65 & 71 & 70 & 55 & 9 \\
\hline Deposits with BPA & 5 & 3 & 5 & 16 & -19 \\
\hline Claims on government (net) & -18 & -23 & -27 & -28 & -34 \\
\hline Claims on private sector & 88 & 106 & 111 & 100 & 102 \\
\hline Capital accounts & -14 & -15 & 23 & 19 & 12 \\
\hline Other items (net) & 4 & 1 & -43 & -52 & -52 \\
\hline Deposit liabilities & 66 & 77 & 99 & 143 & 191 \\
\hline Demand deposits & 31 & 38 & 52 & 73 & 102 \\
\hline Time and Savings Deposits & 34 & 38 & 46 & 68 & 88 \\
\hline Deposits Excluded from Broad Money & 1 & 1 & 1 & 2 & 1 \\
\hline \multicolumn{6}{|l|}{ Memorandum items } \\
\hline Petroleum Fund balance (US\$ millions) 1/ & $\ldots$ & 370 & 1,012 & 2,086 & 4,197 \\
\hline Net foreign assets (percentage change) & 70.0 & -13.4 & -28.8 & 181.1 & 23.4 \\
\hline Credit to the private sector (percentage change) & 237.2 & 19.8 & 5.2 & -9.8 & 1.9 \\
\hline Credit ratio to non-oil GDP (percent) & 28.6 & 31.9 & 34.1 & 25.3 & 20.5 \\
\hline Broad money ratio to non-oil GDP (percent) & 21.3 & 23.5 & 30.6 & 36.1 & 38.6 \\
\hline Credit ratio to deposits (percent) & 133.9 & 137.4 & 112.5 & 70.1 & 53.5 \\
\hline
\end{tabular}

Sources: Banking and Payments Authority; and Fund staff estimates.

1/ An oil fund was created in September 2005 and the deposits were moved off-shore and onto the Government balance sheet.

2/ Includes only coinage issued by the BPA. No data is available for notes due to dollarization of the financial system.

3 / Includes 3 commercial banks (branches of foreign banks) and a micro-finance institution. 
Table 7. Timor-Leste: Medium-Term Outlook, 2006-2014 (Strong Policy Scenario)

\begin{tabular}{|c|c|c|c|c|c|c|c|c|c|}
\hline & 2006 & 2007 & 2008 & 2009 & 2010 & 2011 & 2012 & 2013 & 2014 \\
\hline & & & & \multicolumn{6}{|c|}{ Staff Projections } \\
\hline \multicolumn{10}{|l|}{ Output and prices } \\
\hline GNI at current prices (in millions of US dollars) & 972 & 1,728 & 2,915 & 2,198 & 2,312 & 2,982 & 3,266 & 3,102 & 3,281 \\
\hline Of which: Non-oil GDP & 327 & 398 & 499 & 590 & 659 & 733 & 808 & 889 & 978 \\
\hline Petroleum revenue & 637 & 1,312 & 2,399 & 1,588 & 1,633 & 2,236 & 2,445 & 2,200 & 2,290 \\
\hline Real non-oil GDP growth (percentage change) & -5.8 & 8.4 & 12.8 & 7.4 & 7.5 & 7.4 & 6.6 & 6.2 & 5.9 \\
\hline Including United Nations $1 /$ & -3.4 & 16.8 & 12.2 & 8.0 & 2.0 & -1.4 & 5.8 & 5.6 & 5.9 \\
\hline Inflation (percentage change, period average) & 4.1 & 8.9 & 7.6 & 1.3 & 4.0 & 4.0 & 4.0 & 4.0 & 4.0 \\
\hline & \multicolumn{9}{|c|}{ (in percent of non-oil GDP) } \\
\hline \multicolumn{10}{|l|}{ Investment-saving balance } \\
\hline Gross investment 2/ & 23 & 26 & 46 & 51 & 54 & 47 & 36 & 35 & 33 \\
\hline Gross national saving & 188 & 322 & 451 & 242 & 225 & 281 & 276 & 225 & 216 \\
\hline External saving & -165 & -296 & -405 & -191 & -171 & -234 & -240 & -190 & -183 \\
\hline \multicolumn{10}{|l|}{ Central government finances } \\
\hline Revenues & 205 & 343 & 490 & 279 & 257 & 315 & 314 & 259 & 247 \\
\hline Domestic revenue & 10 & 11 & 9 & 10 & 9 & 10 & 11 & 12 & 13 \\
\hline Petroleum revenue & 195 & 330 & 481 & 269 & 248 & 305 & 303 & 247 & 234 \\
\hline Grants & 0 & 3 & 0 & 0 & 0 & 0 & 0 & 0 & 0 \\
\hline Expenditure & 32 & 59 & 106 & 101 & 94 & 81 & 68 & 64 & 60 \\
\hline Recurrent expenditure & 27 & 46 & 70 & 63 & 53 & 47 & 45 & 41 & 39 \\
\hline Capital expenditure & 5 & 13 & 36 & 38 & 41 & 34 & 23 & 22 & 21 \\
\hline Overall balance & 174 & 284 & 384 & 178 & 162 & 234 & 246 & 196 & 187 \\
\hline Non-oil fiscal balance & -21 & -46 & -97 & -91 & -85 & -71 & -57 & -52 & -47 \\
\hline \multicolumn{10}{|l|}{ Combined sources fiscal operations $3 /$} \\
\hline Revenues & 13 & 15 & 11 & 12 & 11 & 13 & 15 & 16 & 17 \\
\hline Expenditure & 73 & 88 & 144 & 136 & 126 & 108 & 89 & 81 & 75 \\
\hline Overall balance & -60 & -73 & -134 & -125 & -115 & -95 & -75 & -65 & -58 \\
\hline & \multicolumn{9}{|c|}{ (in millions of U.S. dollars, unless otherwise specified) } \\
\hline \multicolumn{10}{|c|}{ 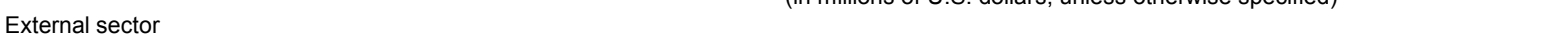 } \\
\hline Current account balance & 540 & 1,177 & 2,021 & 1,127 & 1,127 & 1,715 & 1,938 & 1,693 & 1,788 \\
\hline Trade balance & -91 & -169 & -339 & -431 & -457 & -445 & -434 & -436 & -437 \\
\hline Merchandise exports 4/ & 9 & 7 & 14 & 10 & 13 & 14 & 16 & 18 & 20 \\
\hline Merchandise imports & 101 & 176 & 353 & 440 & 469 & 459 & 450 & 454 & 456 \\
\hline Petroleum revenue & 637 & 1,312 & 2,399 & 1,588 & 1,633 & 2,236 & 2,445 & 2,200 & 2,290 \\
\hline Overall balance & -70 & 147 & -20 & 47 & -69 & -3 & -7 & 4 & 4 \\
\hline Public foreign assets (end-period) & 1,096 & 2,316 & 4,407 & 5,367 & 6,385 & 8,073 & 10,050 & 11,791 & 13,622 \\
\hline (in months of merchandise imports) & 131 & 158 & 150 & 146 & 163 & 211 & 268 & 312 & 358 \\
\hline \multicolumn{10}{|c|}{ (in percent of non-oil GDP, unless otherwise specified) } \\
\hline Current account & 165 & 296 & 405 & 191 & 171 & 234 & 240 & 190 & 183 \\
\hline Trade balance & -28 & -43 & -68 & -73 & -69 & -61 & -54 & -49 & -45 \\
\hline Merchandise exports 4/ & 3 & 2 & 3 & 2 & 2 & 2 & 2 & 2 & 2 \\
\hline Merchandise imports & 31 & 44 & 71 & 75 & 71 & 63 & 56 & 51 & 47 \\
\hline Overall balance & -21 & 37 & -4 & 8 & -10 & 0 & -1 & 0 & 0 \\
\hline \multicolumn{10}{|l|}{ Memorandum items: } \\
\hline Crude oil price ( $\$$ per barrel) 5/ & 64 & 71 & 97 & 61 & 75 & 78 & 80 & 81 & 83 \\
\hline Petroleum Fund withdrawals & 0 & -75 & -79 & -100 & -75 & -71 & -56 & -52 & -47 \\
\hline Petroleum Fund balance (end-period) & 310 & 525 & 841 & 866 & 940 & 1,076 & 1,222 & 1,305 & 1,374 \\
\hline Public debt & 0 & 0 & 0 & 0 & 0 & 0 & 0 & 0 & 0 \\
\hline
\end{tabular}

Sources: Data provided by the Timor Leste authorities; and Fund staff estimates and projections.

1/ Includes locally paid compensation of UN peacekeeping mission staff.

2/ Excludes oil/gas sector investment.

3/ Includes autonomous agencies and fiscal and quasi-fiscal expenditure programs undertaken by

bilateral donors and international financial institutions outside the central government budget.

4/ Excludes oil/gas revenue, which is recorded under the income account.

5/ Simple average of three spot prices; Dated Brent, West Texas Intermediate, and the Dubai Fateh. 
Table 8. Timor-Leste: Vulnerability Indicators, 2004-2008

\begin{tabular}{|c|c|c|c|c|c|}
\hline & 2004 & 2005 & 2006 & 2007 & 2008 \\
\hline \multicolumn{6}{|l|}{ Financial sector risk indicators } \\
\hline Public debt $1 /$ & 0.0 & 0.0 & 0.0 & 0.0 & 0.0 \\
\hline Broad money (percent change, 12-month basis) 2/ & & 18.3 & 28.2 & 43.9 & 34.1 \\
\hline Private Sector credit (percent change, 12-month basis) & & 19.8 & 5.2 & -9.8 & 1.9 \\
\hline \multicolumn{6}{|l|}{ External indicators } \\
\hline Goods exports (percent change, 12-month basis in U.S. dollars) & 0 & 3 & 14 & -28 & 111 \\
\hline Goods imports (percent change, 12-month basis in U.S. dollars) & 6 & -8 & -11 & 75 & 101 \\
\hline Current account balance & 21 & 78 & 165 & 296 & 405 \\
\hline Public foreign assets (in millions of U.S. dollars) $3 /$ & 182 & 524 & 1,096 & 2,316 & 4,407 \\
\hline (in months of corresponding imports of goods) & 18 & 56 & 131 & 158 & 150 \\
\hline Net Foreign assets of commercial banks (in millions of U.S. dollars) & 1 & 6 & 29 & 88 & 182 \\
\hline Total external debt $1 /$ & 0 & 0 & 0 & 0 & 0 \\
\hline External debt-service (in percent of exports of goods and services) & 0 & 0 & 0 & 0 & 0 \\
\hline
\end{tabular}

Sources: Timor-Leste authorities; and Fund staff estimates.

$1 /$ No external or domestic debt has been contracted.

2/ Excludes currency in circulation on which no data are available.

3/ Includes investments of Petroleum Fund assets overseas. 
Appendix I. Authorities' Response to Recent Fund Policy Advice

Advice from the 2008 Article IV Discussions
Exchange Rate Policy
Action Taken
$\begin{array}{ll}\text { Maintain current monetary and exchange regime } & \text { Continued commitment to build up institutional capacity } \\ \text { until institutional capacity is built. } & \text { before any policy change. }\end{array}$

Fiscal Policy

Preserve the basic principles of the Petroleum Fund Petroleum Fund Law under review to allow greater framework. diversification; basic principles expected to stay.

Address obstacles to budget execution, especially in Spending sharply increased, with improved execution of investment spending capital budget, but quality uneven.

Enhance planning by moving budget to cash basis, Budget moved to cash basis, medium-term framework introducing medium-term fiscal framework, and developed, and strategic framework targeted for updating NDP. completion by end-year.

\section{Financial Sector Policy}

Pass pending financial sector laws and facilitate Central Bank and AML laws being considered by contract enforcement. Cabinet; other legislation still pending.

Continue strengthening of banking supervision and Banking supervision enhancement continuing and credit introduce credit registry. registry ready for introduction.

Ensure that public involvement in sector is on Government assumed ownership of IMFTL; authorities commercial terms and supervised under law. affirm plans to run on commercial basis.

\section{Structural Reforms}

Improve environment for private activity Strengthen statistical capacity.
Land law progressing but other steps still pending. BOP statistics published and resources provided for national accounts. 


\section{INTERNATIONAL MONETARY FUND \\ DEMOCRATIC REPUBLIC OF TIMOR-LESTE}

\section{Staff Report for the 2009 Article IV Consultation-Informational Annex}

Prepared by the Staff Representatives for the 2009 Consultation with Timor-Leste

(In Consultation with Other Departments)

July 8, 2009

Contents

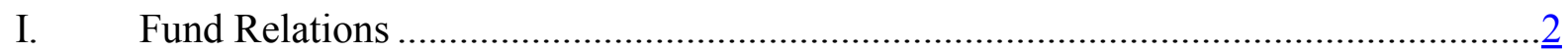

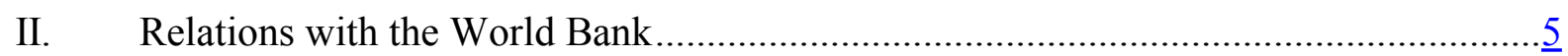

III. Relations with the Asian Development Bank ……...............................................

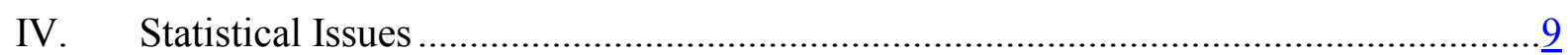

V. Poverty Reduction: The Role of Infrastructure ………………...............................

VI. Prospects for Financial Development: The Emerging Role of Micro-Finance..............15 


\section{ANNEX I. TIMOR-LESTE: FUND RELATIONS}

(As of May 29, 2009)

I. Membership Status: Joined 7/23/2002; Article VIII

II. General Resources Account:

SDR Million

\% Quota

Quota

8.20

100.00

Fund holdings of currency

8.20

100.00

Reserve position in Fund

0.00

0.01

III. SDR Department:

SDR Million

$\%$ Allocation

Holdings

0.00

N/A

IV. Outstanding Purchases and Loans:

None

V. Latest Financial Arrangements: None

VI. Projected Obligations to Fund: None

VII. Exchange Rate Arrangements

On January 24, 2000, the U.S. dollar was adopted as the official currency of then East Timor by the United Nations Transitional Administration in East Timor (UNTAET). This arrangement has been maintained after Timor-Leste's independence on May 20, 2002. At present, the monetary authority does not undertake foreign exchange transactions; they are handled by commercial banks on the basis of rates quoted in the international markets.

\section{Article IV Consultations}

The 2008 Article IV consultation discussions with the authorities were held during April 16-30, 2008; the consultation was concluded on June 25, 2008. The Public Information Note may be found at http://www.imf.org/external/np/sec/pn/2008/pn0878.htm.

\section{Technical Assistance}

Since late 1999, a significant amount of technical assistance has been provided by the Fund as part of the international community's efforts to 
reconstruct the Timor-Leste economy. The Fund's technical assistance has focused on establishing key economic institutions (especially fiscal and monetary authorities) essential for macroeconomic management, as well as on developing local capacity to manage them. It also played a key role in the adoption of a new currency arrangement based on the U.S. dollar. Since late 1999, Timor-Leste has been one of the largest recipients of Fund technical assistance.

FAD: A series of multi-topic FAD missions took place early on to establish and develop the Central Fiscal Authority (CFA, February 2000), which developed into the Ministry of Planning and Finance. Assistance was provided to develop budget preparation, establish tax policy and administration, strengthen treasury and expenditure management, and advise on oil sector fiscal regimes. Long-term resident advisors were assigned to the Ministry of Planning and Finance and the Revenue Service of Timor-Leste to cover a wide range of issues, partly under a cost sharing arrangement with the UN. Over August 2004-July 2005, a FAD resident advisor assisted in the design and establishment of the Petroleum Fund, which started operations in August 2005. A FAD resident advisor to the Treasurer of the ministry finance started work in December 2006 to help strengthen expenditure management, reporting and budget execution - after a short break, a replacement has continued this work since July 2008. In 2007, a FAD TA mission provided guidance for future reform of the non-oil tax regime. In April 2009 a FAD technical assistance mission provided advice on implementation of the fiscal regimes for petroleum.

LEG: A number of LEG missions have been to Timor-Leste to advise the authorities on key fiscal and financial legislation. These included tax legislation, the budget and financial management law, and banking regulations (relating to the monetary authority, the banking system, and the payments system). Jointly with MFD (now MCM), technical assistance has been provided to assist in drafting an Anti-Money Laundering and Combating the Financing of Terrorism (AML/CFT) Law. LEG has also provided assistance, in collaboration with FAD, for the drafting of the Petroleum Fund Act and tax consolidation, and in collaboration with MCM, for the drafting of the Central Bank Law.

MCM: A large number of missions took place early on to establish and develop the Central Payments Office (CPO, January 2000), which was transformed subsequently into the Banking and Payments Authority (BPA) (November 2001). Assistance was provided to establish a payments system, prepare banking legislation, and develop key functions of the monetary authority, including banking supervision, asset management, accounting, and organization and 
management. Assistance was also provided on the introduction of a dollar-based currency system and to issue domestic coins to supplement the use of U.S. dollar coins. More recently, assistance has been provided to (i) draft the insurance law and develop a framework for insurance supervision; (ii) strengthen banking supervision; (iii) address a broad range of issues related to AML/CFT; (iv) establish and train the investment unit responsible for managing petroleum fund assets (funded by Norway, a resident adviser commenced in March 2005 and, after a break due to contract renegotiations, a replacement continued this work from November 2008); (v) prepare for the establishment of the central bank; (vi) design of a more effective organizational structure at the BPA; and (vii) modernize payment systems, and accounting for the Petroleum Fund. In addition, up until 2006 long-term resident advisors, including on banking supervision, payments, and accounting, have been assigned to the BPA under a cost-sharing arrangement with the UN. A long-term resident advisor assisted the BPA General Manager from February 2005 until February 2008, with that support subsequently provided on a peripatetic basis and funded by a Japanese grant.

STA: A multi-sector statistical mission took place in November 2000 to assess the availability and quality of official macroeconomic data, and help establish the Statistic Division of the Ministry of Planning and Finance. Assistance was provided by long term statistical advisors during November 2001-October 2005. Since 2007, a peripatetic statistical advisor has provided assistance for improving data compilation and developing local capacity to prepare balance of payments statistics - responsibility for this was transferred to the BPA in 2007. Provisional annual balance of payments statements for 2006 and 2007 were published in December 2008. In early 2008 a monetary and financial statistics (MFS) mission helped introduce the standardized report forms (SRFs) for reporting monetary data to the IMF and an integrated monetary database. Subsequently, Timor-Leste has, for the first time, been able to publish a country page in IFS. A March 2009 follow-up MFS mission assisted in expanding the institutional coverage of depository corporations to include microfinance institutions and in revising the call report form that will be used to collect balance sheet data.

\section{Resident Representative}

A resident representative office was established in Dili in August 2000. The current resident representative, Mr. Tobias Rasmussen, assumed the post in February 2006. The resident representative office closed at end-June 2009. 


\section{ANNEX II. TIMOR-LESTE: RELATIONS WITH THE WORLD BANK GROUP}

(As of May 25, 2009)

1. Timor-Leste joined the World Bank Group on July 23, 2002. It became eligible for IDA assistance on October 9, 2002. Thus far, there has been no lending to Timor-Leste, reflecting the authorities' policy to avoid external borrowing, including concessional loans. However, the World Bank has been actively involved in the reconstruction and development of the economy since late 1999, by playing a key catalytic role in mobilizing and coordinating international assistance to Timor-Leste. Timor-Leste joined IFC in September 2004 and, together with the Pacific Enterprise Development Facility, an office was opened in Dili in 2006.

2. During the transition to independence, the World Bank's involvement centered around its role as trustee and co-manager of the Trust Fund for East Timor (TFET), which was established in December 1999 as a vehicle to provide grant assistance for reconstruction activities and economic development in Timor-Leste. Under the TFET, which is co-managed with the Asian Development Bank (ADB), the World Bank has administered projects relating to social services (especially health and education), agriculture, private sector development, community development and governance, economic capacity building, and petroleum sector development. ${ }^{1}$

3. In addition to its involvement through the TFET, the World Bank played a key role in mobilizing budgetary assistance for the post-independence period through an annual multidonor budget support operation. The Transition Support Program (TSP) from FY 2003 to 2005, was followed by the Consolidation Support Program (CSP) to FY2006/07, to reflect the shift from post-conflict transition to consolidation of gains made thus far. The TSP programs brought about $\$ 30$ million in budget support annually with about $\$ 5$ million financed by IDA, and the balance financed by 9 bilateral partners. The CSP program brought around $\$ 10$ million in budget support annually, with about $\$ 0.5$ million financed by IDA. Both the TSP and the CSP programs focused on three thematic areas: (1) good governance, including developing a legal framework for governance and the judiciary and strengthening public expenditure management; (2) service delivery for poverty reduction, particularly in education and health; and (3) job creation, especially through private sector development, agriculture, and improvements in basic infrastructure.

\footnotetext{
${ }^{1}$ Pledges to the TFET were made by 12 donors, including the European Commission and the World Bank, with the total amount of funds reaching $\$ 178$ million. This comprises donors' contributions of $\$ 167$ million (including $\$ 10$ million by the World Bank) and investment income of $\$ 9$ million. TFET projects are expected to wind down by end-2010.
} 
4. The World Bank has also provided analytical and advisory services, including through a Country Economic Memorandum, a Poverty Assessment, a Public Expenditure Management and Accountability Note, a Public Expenditure Review, an Education Sector Review, and a Paper on Strengthening the Institutions of Governance in Timor-Leste. The "Doing Business" report for 2006 featured Timor-Leste for the first time and was updated for 2007 and for 2008. The World Bank has also produced short, just-in-time reports on Key Lessons from the Creation of Veterans Policy in Timor-Leste (September 2008), Policy Note on Population Growth and its Implications in Timor-Leste (October 2008), and Timor-Leste: Poverty in a Young Nation (November 2008).

5. In July 2005 the World Bank adopted a Country Assistance Strategy for FY 2006-08. The International Development Association (IDA) and the International Finance Corporation (IFC) are currently preparing an Interim Strategy Note, scheduled to be presented to the Board of Executive Directors in June 2009. As of March 2009, the World Bank Group had a total commitment of US\$69.8 million (including an IDA commitment of US\$12.4 million) with 9 active projects in the health and education sectors, in agriculture, in support to youth development, in planning and public financial management, and in the energy sector.

6. As budget support is no longer required given the increase in petroleum revenue, the CSP program was replaced by donor support for the Government's National Priorities Program launched in 2008. The annual program was continued in 2009 and included seven priority areas: (i) agriculture and food security; (ii) rural development; (iii) human resources development; (iv) social protection and social services; (v) public safety and security; (vi) clean and effective Government; (vii) access to justice.

7. The eighth and latest Timor-Leste Development Partners Meeting (TLDPM) took place on April 2-4, 2009. The World Bank helped the preparation of the Government's background paper to the TLDPM. 


\section{ANNEX III. TIMOR-LeSTE: RELATIONS WITH THE ASIAN DEVELOPMENT BANK}

(As of May 26, 2009)

1. Timor-Leste joined the Asian Development Bank (AsDB) on July 24, 2002. To date, there has been no lending to the country. However, like other international financial institutions and bilateral donors, the AsDB has been actively involved in the reconstruction and development of the economy since late 1999 .

2. Prior to 2008 the AsDB's involvement centered around co-managing with the World Bank the Trust Fund for East Timor (TFET), which was established in December 1999 as a vehicle to provide grant assistance for reconstruction activities and economic development in Timor-Leste. ${ }^{2}$ Under the TFET, AsDB managed six projects with total funding of $\$ 51.7$ million, ${ }^{3}$ which aimed at the rehabilitation of physical infrastructure (urban and rural power, national roads, ports, and water and sanitation) and the development of microfinance. In the wake of the post-referendum destruction, the focus of the projects was on providing emergency assistance, but subsequently shifted to meeting the country's long-term development needs.

3. The AsDB's Country Operations Business Plan for 2008 to 2010 identifies infrastructure development and management as the primary focus of AsDB support to TimorLeste. An ongoing road rehabilitation project (\$10 million grant) and Dili water supply project (\$6 million grant) are funded through the $9^{\text {th }}$ Asian Development Fund (ADF IX). The recently negotiated ADF $X$ allocates approximately $\$ 20$ million for the first biennial period 2009-2010, entirely on a grant basis. Most of this money will support road maintenance, rehabilitation, and improvement. Additional AsDB technical assistance will average approximately $\$ 2$ million per annum. Allocations will be confirmed in a new Country Partnership Strategy for 2009-2013. Timor-Leste is the recipient of AsDB's largest ever technical assistance (TA) grant, the Infrastructure Project Management TA. This \$15 million four-year package, co-financed with AusAID, finances international and domestic project engineers, procurement specialists, and others to work within the Ministry of Infrastructure to help plan, prepare, and execute the Government's capital development program.

\footnotetext{
${ }^{2}$ See footnote 1 in Annex II, Relations with the World Bank Group.

${ }^{3}$ These projects comprise the Emergency Infrastructure Rehabilitation Project (\$29.8 million); the Emergency Infrastructure Rehabilitation Project 2 (\$9 million); the Water Supply and Sanitation Rehabilitation Project (\$4.5 million); the Water Supply and Sanitation Rehabilitation Project 2 (\$4.5 million); the Hera Fisheries Port Facilities Rehabilitation Project ( $\$ 1$ million); and the Microfinance Development Project (originally $\$ 4$ million, but reduced to $\$ 2.7$ million).
} 
4. AsDB is currently preparing a new ADF-funded project in road network development and a project on community based roads maintenance drawing on the Japan Fund for Poverty Reduction. A regional private sector development support program, can also support access to finance (micro-finance and secured transactions) and public-private-partnerships in infrastructure development. AsDB has also intensified efforts to strengthen and divest the Microfinance Institute of Timor-Leste (IMfTL). It is also designing a technical assistance program in support of statistics and macro economic management. 


\section{ANNEX IV. TIMOR-LESTE: STATISTICAL ISSUES}

As of June 30, 2009

\section{Assessment of Data Adequacy for Surveillance}

General: Data provision to the Fund has serious shortcomings that significantly hamper surveillance. Weaknesses remain in the macroeconomic data, especially the national accounts. A multi-sector Fund statistics mission visited Dili in November 2000 and assisted the authorities in establishing objectives for restoring economic statistics and in setting up a Statistical Division in the Ministry of Planning and Finance in 2001. A long-term resident statistical advisor assisted the Statistical Division during November 2001-February 2004, and was succeeded by a new resident advisor until September 2005. Technical assistance in balance of payments (peripatetic) and monetary statistics to the Banking and Payments Authority (BPA) began in mid 2007 and January 2008, respectively, and will continue through at least FY 2010.

National Accounts: Under a World Bank-financed project, national accounts data for 2000 (both sector and expenditure basis) were estimated by the Boston Institute for Developing Economies (BIDE). In late 2004, BIDE, under a follow-up World Bank project, produced GDP estimates for 2001-03 that suffer from limited source data and substantial extrapolation. The Statistics Directorate has not been able to replicate the BIDE estimation exercise. Consequently, estimates of GDP (including for the oil sector) have been prepared by Fund staff in cooperation with the Macroeconomic Unit in the Ministry of Finance. To improve national accounts data, appropriate staff and substantial efforts in data collection and compilation are needed. Using World Bank funding and commencing in April 2009, the authorities are employing a consultant to develop annual estimates of GDP.

Price statistics: A consumer price index has been compiled for Dili since December 2001 and for the whole country since June 2003. Prices for all items in the basket are collected on a monthly basis in the Dili region. Elsewhere, prices are collected at quarterly intervals for a representative selection of other regions throughout Timor-Leste. The measure of the interim monthly price movements for each item outside the Dili region is then estimated using the corresponding Dili region item price movement as an indicator series. To address quality weaknesses, in particular inappropriate and outdated weights, the commodity basket and the weighting scheme were revised in mid-2003 under a donor-supported project. A further update of CPI weights based on detailed consumption patterns is expected to commence later in 2009 using data derived from the Timor-Leste Living Standards Survey that was conducted in 2006/7. An update of products and outlets is also needed.

Labor market statistics: Annual data on public sector employment and wages are available in official budget documentation. No official data are compiled regularly on private sector employment and wages, except for partial data from various household surveys conducted by UNDP, ILO, ADB, and the World Bank. 
Government finance statistics: Official data on central government revenue and expenditure are published quarterly. Audited annual financial statements of the executed budget are made available to APD as soon as they are released, normally three months after the end of the fiscal year. In addition, monthly data are available on request through the budget, treasury, and revenue services. The compilation of revenue and expenditure follows the classification of the Manual on Government Finance Statistics (GFSM 1986) (including expenditure based on both functional and economic classification). Only partial data are available on fiscal and quasi-fiscal activities undertaken by bilateral donors outside the central government budget. Currently, there are four non-financial public enterprises, which are treated as government agencies and data on their operations are available in the audited annual financial statements. No data are currently reported for the GFS Yearbook and the International Financial Statistics.

Monetary statistics: Monetary statistics are compiled by the BPA, generally following the methodology of the Monetary and Financial Statistics Manual. However, data are incomplete because of the absence of official data on public currency holdings - which are difficult to compile under the current currency regime - and of banks' positions with public nonfinancial corporations. The BPA publishes current monetary data on its website on a regular monthly basis and a quarterly bulletin and an annual report with key monetary aggregates.

Detailed monthly monetary data are now available from July 2002 onward following the introduction of the standardized report forms (SRFs). Beginning in February 2008, monetary data are reported to the IMF for publication in the International Financial Statistics. SRFbased data are used for the Fund's operational and publication purposes. The BPA is planning to introduce a new chart of accounts for the BPA in the coming months and a revised call report form (CRF) in mid-2009 to obtain balance-sheet information from other depository corporations (ODCs). A March 2009 mission assisted the authorities in finalizing the design of the CRF and expanded the institutional coverage of the ODCs to include all microfinance institutions. A follow-up mission has been tentatively scheduled during FY 2010 to assist the authorities in introducing the SRFs for the central bank based on the new chart of accounts of the BPA and for the ODCs based on the revised CRF and including the credit unions in the institutional coverage of the ODCs.

Balance of payments: Monthly data on merchandise exports and imports have been produced starting March 2000, based on customs reports with a breakdown for major commodity categories. Data do not include oil and gas exports or an estimate of the large, unrecorded border trade. The monthly trade data are now published regularly but there are significant gaps in the series for 2006 and 2007. In the Fund staff estimates, data on oil/gas revenue are currently recorded as current income based on fiscal data.

With technical assistance provided by the IMF's Statistics Department, annual balance of payments data for 2006 and 2007 were published by the BPA in December 2008. The 2008 estimates have not yet been finalized.

While methodology for the production of basic annual estimates of the balance of payments statistics are in place, further development work is anticipated to address limitations of existing data sources, in particular grants, merchandise trade statistics, and travel exports. 
The coverage of the survey of foreign direct investment enterprises needs to be expanded, and the exploration and extraction activities, in the Joint Petroleum Development Area and in the exclusive territory, will require continuous coverage. As the economy grows, it will be important to monitor new activities such as new direct investment. Currently, there is limited information on remittances from Timorese working abroad and improvement in the estimation/compilation procedures of such remittances should be pursued.

Some data on stocks of financial assets and liabilities have been collected as the balance of payments development has taken place, and the annual international investment position statements should be finalized. Development of quarterly statistics should also be pursued.

\section{Data Standards and Quality}

Not a General Data Dissemination System No data ROSC is available. participant. 
Timor-Leste: Table of Common Indicators Required for Surveillance

(As of June 24, 2009)

\begin{tabular}{|c|c|c|c|c|c|}
\hline & $\begin{array}{c}\text { Date of } \\
\text { latest } \\
\text { observatio } \\
n\end{array}$ & $\begin{array}{l}\text { Date } \\
\text { receive } \\
\quad \text { d }\end{array}$ & $\begin{array}{c}\text { Frequenc } \\
\text { y of } \\
\text { Data }^{6}\end{array}$ & $\begin{array}{l}\text { Frequenc } \\
\quad \text { y of } \\
\text { Reporting }^{6}\end{array}$ & $\begin{array}{c}\text { Frequency } \\
\text { of } \\
\text { publication } \\
6\end{array}$ \\
\hline Exchange Rates & $5 / 2009$ & $6 / 2009$ & M & M & M \\
\hline $\begin{array}{l}\text { International Reserve Assets and Reserve } \\
\text { Liabilities of the Monetary Authorities }^{1}\end{array}$ & $5 / 2009$ & $6 / 2009$ & M & M & M \\
\hline $\begin{array}{l}\text { Reserve/Base Money (excludes currency in } \\
\text { circulation) }\end{array}$ & 52009 & $6 / 2009$ & M & M & M \\
\hline $\begin{array}{l}\text { Broad Money (excludes currency in } \\
\text { circulation) }\end{array}$ & $5 / 2009$ & $6 / 2009$ & M & M & M \\
\hline Central Bank Balance Sheet & $5 / 2009$ & $6 / 2009$ & M & M & M \\
\hline $\begin{array}{l}\text { Consolidated Balance Sheet of the Banking } \\
\text { System }\end{array}$ & $5 / 2009$ & $6 / 2009$ & M & M & M \\
\hline Interest Rates $^{2}$ & $5 / 2009$ & $6 / 2009$ & M & M & M \\
\hline Consumer Price Index & $3 / 2009$ & $5 / 2009$ & M & M & Q \\
\hline $\begin{array}{l}\text { Revenue, Expenditure, Balance and } \\
\text { Composition of Financing }^{3}-\text { General } \\
\text { Government }\end{array}$ & $\cdots$ & $\ldots$ & $\cdots$ & $\cdots$ & $\ldots$ \\
\hline $\begin{array}{l}\text { Revenue, Expenditure, Balance and } \\
\text { Composition of Financing }{ }^{3}-\text { Central } \\
\text { Government }\end{array}$ & $3 / 2009$ & $6 / 2009$ & Q & Q & Q \\
\hline $\begin{array}{l}\text { Stocks of Central Government and } \\
\text { Central Government-Guaranteed Debt }\end{array}$ & & & o debt contr & ted & \\
\hline External Current Account Balance & 2007 & $12 / 2008$ & A & A & A \\
\hline Exports and Imports of Goods and Services ${ }^{5}$ & $4 / 2009$ & $6 / 2009$ & M & M & M \\
\hline GDP/GNI & 2003 & $10 / 2004$ & $\ldots$ & $\ldots$ & $\ldots$ \\
\hline Gross External Debt & \multicolumn{5}{|c|}{ Not applicable } \\
\hline International Investment Position ${ }^{7}$ & \multicolumn{5}{|c|}{ Not available } \\
\hline
\end{tabular}

\footnotetext{
${ }^{1}$ Includes reserve assets pledged or otherwise encumbered as well as net derivative positions.

${ }^{2}$ Both market-based and officially-determined, including discount rates, money market rates, rates on treasury bills, notes and bonds.

${ }^{3}$ Foreign, domestic bank, and domestic nonbank financing.

${ }^{4}$ The general government consists of the central government (budgetary funds, extra budgetary funds, and social security funds) and state and local governments. For Timor-Leste it includes public spending from donors, on which regular data on execution are not available.

${ }^{5}$ Includes only goods. There are significant gaps in the series. No information on services is available.

${ }^{6}$ Daily (D), Weekly (W), Monthly (M), Quarterly (Q), Annually (A); NA: Not Available.

${ }^{7}$ Includes external gross financial asset and liability positions vis-à-vis nonresidents.
} 


\section{AnNeX V. Poverty Reduction: The Role OF INFRASTRUCTURE}

Timor-Leste is one of the poorest countries in Asia. A 2001 household income and expenditure study estimated that 36 percent of the population lived below the national poverty line, almost all of whom were in rural areas with poor access to water, sanitation and health care. A 2007 update suggests that many key dimensions of living standards have improved, as shown by improved self-assessments of living standards, and in school enrolment rates, immunization rates and the availability of many basic services. ${ }^{5}$ However, the share of the population living below the poverty line was found to have increased to about 50 percent. Half of the children less than five years were underweight in 2007, with 12 percent to 18 percent of children under five years severely underweight. Large gaps remain in access to education and health care and other essential services and in the quality of these services. Living standards are noticeably lower in rural areas, with about three quarters of the poor living in rural areas.

Shortcomings in infrastructure appear to be central to the poverty problem. They make it more difficult for the poor to access markets for their products and essential services and add to the cost of goods and services needed by the poor. The poor are also more likely to face the shortcomings in infrastructure. For example, at the national level, 64 percent of the poor have access to all weather roads, compared with 76 percent of the non-poor. And in rural areas the proportion of poor with access to all weather roads decreases further to 58 percent compared with 68 percent of the non-poor.

Much of Timor-Leste's infrastructure was badly damaged immediately following the referendum in 1999, either during the violence that ensued or subsequently because of the damage from heavy vehicles, lack of maintenance or heavy rain. Despite efforts at rehabilitation, critical infrastructure has deteriorated further since then. This is particularly the case for the road network.

Road is the primary mode of transport, carrying 70 percent of freight and 90 percent of passengers. Timor-Leste has an extensive road network of about $6,000 \mathrm{~km}$, half of which are currently undeveloped rural tracks. The core network comprises $1,400 \mathrm{~km}$ of national roads connecting the 13 districts and $900 \mathrm{~km}$ of district roads linking major population centers to the national roads. About 80 percent (or 1,800 km) of core roads are, or used to be paved. Almost the whole core road network needs rehabilitation works to restore the network to a maintainable condition as road conditions demonstrate premature deterioration due to lack of routine and preventive maintenance. This is compounded by intense rainfalls and unstable geotechnical conditions in mountainous areas causing frequent landslides.

\footnotetext{
${ }^{5}$ Timor-Leste Ministry of Finance, and World Bank. 2008. Timor-Leste: Poverty in a Young Nation. Dili.
} 
According to a recent Asian Development Bank road condition survey, almost the whole core road network has deteriorated into conditions that are no longer maintainable; about 22 percent of the core roads are in poor condition and about 70 percent in very poor condition. The needs of annual maintenance expenditure for the whole core road network are estimated in the order of \$20-30 million under current road conditions.

Power and water supply and sanitation infrastructure are also degraded. Access to regular power supply in urban areas has deteriorated, and access to clean water remains problematic in both urban and rural areas. There are three contributing factors: the poor and deteriorating nature of existing physical infrastructure; cost and logistical issues in accessing rural areas; and weak public sector capacity in terms of infrastructure planning, management and prioritization. 


\section{Annex VI. Prospects for Financial Development: The EMerging Role of Micro-Finance}

While there is a high level of excess liquidity in the financial system, the commercial banks have become reluctant to lend to local businesses. Foreign banks cannot own land and need to rely on land leases or other assets as security. But uncertainty over the legitimacy of land titles and the nascent state of the system of land leases make it difficult for land to be used as collateral. Use of other assets as collateral is hindered by the absence of a local insurance industry. The still developing civil court system is slow as it is heavily overworked, adding to uncertainty in the ability to access security in the event of loan default. These difficulties contributed to the quick emergence of a non-performing loan problem following a surge in domestic credit.

Microfinance has a narrow coverage, but is showing it can find ways of working within the heavily constrained environment. The largest microfinance institution, Instituição de Micro Finanças de Timor-Leste (IMfTL) has operated since 2002. It has built itself on loans secured by public sector salaries. Many loans were for housing and other household needs, but loans were also used within extended families to start small-scale business enterprises, such as small trading and taxi operations. A \$1 million ceiling on deposits under the Banking and Payments Authority (BPA) Act delayed expansion plans (IMfTL is the only microfinance institution regulated by the BPA). The ceiling was lifted to $\$ 3$ million after the government took sole ownership of, and recapitalized, IMfTL in December 2008.

Deposits with IMfTL, from around 23,000 depositors, had reached \$1.4 million by March 2009. Total loans of $\$ 4.0$ million as of March 2009 were well above the $\$ 2.3$ million of December 2007. Seven district offices are now established and offices are planned for all districts by 2011. Salary loans still account for 75 percent of total loans, but alternative products-i.e., micro finance group loans, market vendor loans, agriculture loans and micro enterprises loans - are rising. The salary-backing of most loans and careful lending practices are credited with a low overall provision for non-performing of only 2.2 percent of the total value of loans.

Other key microfinance institutions are Moris Rasik and Tuba Rei Martin. Moris Rasik is the leading microfinance institution for poverty reduction. It operates solely in rural areas and lends only to women, along the lines of the well-known Grameen Bank approach. Total loans were \$2.2 million as of December 2007 and deposits from 11,500 accounts totaled $\$ 0.8$ million. Tuba Rei Martin held around \$0.4 million in deposits from almost 3,000 accounts as of July 2008, with loans of $\$ 0.4$ million. Credit unions, which have a longstanding presence in Timor-Leste, are also active, as are pawn shops, money lenders and a number of small donor-funded loan facilities. 
A recent assessment concluded there is considerable unmet demand for microfinance. ${ }^{6}$ The shortfall was estimated to be as much as 80,000 micro-credit loans worth more than US\$50 million. Lack of credit is a particularly important constraint to agriculture, which accounts for about 80 percent of employment. Agribusiness is hindered because loans are generally unavailable for the purchase of farm inputs or improvements, or for trade in farm products. Micro-savings services are also under-supplied.

Interest rates are high. IMfTL for example lends at 16 percent to 18 percent per annum and rates at Tuba Rei Martin are up to 70 percent per annum. The high interest rates primarily reflect the high cost of providing a large number of small transactions. In an effort to lower interest costs, the Inclusive Finance for the Under-Served Economy (or INFUSE) project has been proposed as source of low cost wholesale funds (and technical support). However, care is needed to ensure that this inflow of foreign funds does not impede deposit taking.

There are long standing proposals for a government-owned national development bank. Key issues to be faced by such a bank would be: the potential to displace rather than supplement existing financial operations; the potential fiscal downside of carrying too much risk in an effort to kick-start development; and whether it is desirable for governments to own financial institutions. An alternative approach could be to provide support through new, targeted programs implemented through existing institutions. An emphasis on helping potential borrowers develop and then implement good loan projects rather than just providing cheap loans is likely to offer the highest development impact.

\footnotetext{
${ }^{6}$ Australian Agency for International Development, 2008, Review of the Microfinance Sector in East Timor, Final Report, December; and Instituição de Micro Finanças de Timor-Leste (IMfTL), personal communication.
} 


\section{IMF Executive Board Concludes 2009 Article IV Consultation with the Democratic Republic of Timor-Leste}

On July 22, 2009, the Executive Board of the International Monetary Fund (IMF) concluded the Article IV consultation with the Democratic Republic of Timor-Leste. ${ }^{1}$

\section{Background}

The Timorese economy has posted high economic growth over the past two years, driven by rapid increases in government spending and a recovery in agriculture from a 2007 drought, and underpinned by improved security conditions. Non-oil real GDP growth reached almost 13 percent in 2008. However, private investment remains small, and Timor-Leste is still among the least developed countries in the world. The global crisis has had little immediate impact on Timor-Leste, as key transmission channels (trade, investment and finance) remain limited. The key adverse impact has been through lower oil prices, which if persistent would reduce the sustainable level of public spending. Inflation peaked at over 10 percent year-on-year in mid2008, but has since declined significantly, along with international food prices. The real exchange rate appreciated, reflecting a weakening of the Indonesian and Australian currencies vis-à-vis the U.S. dollar, and helped reduce inflationary pressures.

Central government spending rose sharply in 2008, reflecting efforts to address pressing development needs and secure social cohesion. Increases in capital spending, current transfers, and rice subsidies were particularly large. However, petroleum revenue soared on

\footnotetext{
${ }^{1}$ Under Article IV of the IMF's Articles of Agreement, the IMF holds bilateral discussions with members, usually every year. A staff team visits the country, collects economic and financial information, and discusses with officials the country's economic developments and policies. On return to headquarters, the staff prepares a report, which forms the basis for discussion by the Executive Board. At the conclusion of the discussion, the Managing Director, as Chairman of the Board, summarizes the views of Executive Directors, and this summary is transmitted to the country's authorities.
} 
the back of high oil/gas prices and an increase in production volumes, leading to an expansion of the fiscal and external surpluses.

The commercial banking sector, consisting of three foreign bank branches, remains very small, and has not been adversely affected by the global financial crisis. Credit has remained stagnant, hampered by a high share of non-performing loans and the lack of effective contract enforcement. Only a small, state-owned microfinance institution has experienced significant credit growth.

The near-term outlook is still positive, with real non-oil GDP growth expected to moderate somewhat but remain at high levels. However, oil prices are expected to remain below their 2008 average, prompting a sharp decline in the fiscal and external surpluses. The medium-term outlook is highly uncertain. Key but hard-to-predict determinants include the path of oil and gas revenue, security conditions, the magnitude and quality of public spending, and progress on reforms to improve the business climate.

\section{Executive Board Assessment}

Executive Directors welcomed Timor-Leste's strong economic growth over the last two years, supported by public spending and improved security, and noted that the global crisis has not had a major impact on the economy given the limited external linkages. Going forward, the key challenge remains to use oil and gas revenue to develop a sustainable non-oil economy and alleviate poverty, while maintaining macroeconomic stability.

Directors welcomed the recently announced moderation in government spending and recommended that expenditure be brought in line with sustainable income as soon as existing commitments allow. They looked forward to the forthcoming Strategic Development Plan, which should provide guidance for a medium-term budget framework aimed at ensuring fiscal sustainability, improving the quality of government spending and public financial management, and strengthening transparency and controls. Directors noted that spending should be carefully prioritized so as to create room for essential infrastructure, health and education expenditure, and better-targeted poverty-reducing transfers. They saw scope to enhance fiscal revenue by improving tax administration, broadening the tax base, and charging appropriate tariffs for utilities, including electricity.

Directors believed that the Petroleum Fund should remain the cornerstone of the country's public financial management. By insulating the budget from petroleum revenue volatility and setting high standards for transparency, they viewed the Petroleum Fund as safeguarding fiscal sustainability and promoting macroeconomic stability. Directors supported a prudent approach toward widening the fund's investment portfolio. They recommended that any foreign borrowing be subject to parliamentary approval and proper justification, be on concessional terms, and deliver a net positive rate of return.

Directors noted that official dollarization has served the country well and has provided a strong nominal anchor for inflation expectations. They observed that fiscal policy needs to be consistent with the exchange rate regime to ensure external sustainability and reduce pressures 
on the real exchange rate. To boost competitiveness, productivity should be enhanced and business climate reforms introduced. Directors recommended passage of the pending land law, strengthening of contract enforcement through judicial reform and adoption of alternative dispute resolution mechanisms, and introduction of eased business regulation, including by simplifying registration and licensing procedures.

While banks have not been adversely affected by the global financial turmoil, Directors welcomed continued efforts to strengthen financial sector supervision and promote financial development. They noted that clearly defined property rights and contract enforcement are needed for financial deepening. Directors underlined the importance of strengthening cooperation with home supervisors of foreign banks and passing legislation to safeguard the Banking and Payment Authority's autonomy.

Directors commended the progress made on the compilation of financial and balance of payments statistics. They encouraged improved monitoring of real sector activity through annual surveys and the compilation of national accounts.

\footnotetext{
Public Information Notices (PINs) form part of the IMF's efforts to promote transparency of the IMF's views and analysis of economic developments and policies. With the consent of the country (or countries) concerned, PINs are issued after Executive Board discussions of Article IV consultations with member countries, of its surveillance of developments at the regional level, of post-program monitoring, and of ex post assessments of member countries with longer-term program engagements. PINs are also issued after Executive Board discussions of general policy matters, unless otherwise decided by the Executive Board in a particular case. The staff report (use the free Adobe Acrobat Reader to view this pdf file) for the 2009 Article IV Consultation with Timor-Leste is also available.
} 
Democratic Republic of Timor-Leste: Selected Economic Indicators, 2004-2010

\begin{tabular}{|c|c|c|c|c|c|c|c|}
\hline & 2004 & 2005 & 2006 & 2007 & 2008 & $\begin{array}{l}2009 \\
\text { Proj. }\end{array}$ & $\begin{array}{l}2010 \\
\text { Proj. }\end{array}$ \\
\hline \multicolumn{8}{|l|}{ Output and prices } \\
\hline GNI at current prices (US\$ million) & 460 & 695 & 972 & 1,728 & 2,915 & 2,198 & 2,312 \\
\hline Non-oil GDP at current prices (US\$ million) & 309 & 332 & 327 & 398 & 499 & 590 & 659 \\
\hline Real non-oil GDP growth (percentage change) & 4.2 & 6.2 & -5.8 & 8.4 & 12.8 & 7.4 & 7.5 \\
\hline Including United Nations $1 /$ & 0.4 & 2.3 & -3.4 & 16.8 & 12.2 & 8.0 & 2.0 \\
\hline Inflation (CPI, percentage change, end-period) & 2.5 & 1.0 & 6.7 & 7.6 & 6.1 & 2.3 & 4.0 \\
\hline \multirow[t]{2}{*}{ Inflation (CPI, percentage change, period average) } & 3.2 & 1.8 & 4.1 & 8.9 & 7.6 & 1.3 & 4.0 \\
\hline & \multicolumn{7}{|c|}{ (In percent of non-oil GDP) } \\
\hline Investment-saving balance & & & & & & & \\
\hline Gross investment 2/ & 21 & 21 & 23 & 26 & 46 & 51 & 54 \\
\hline Gross national savings & 42 & 99 & 188 & 322 & 451 & 242 & 225 \\
\hline External savings & -21 & -78 & -165 & -296 & -405 & -191 & -171 \\
\hline \multicolumn{8}{|l|}{ Central government finances } \\
\hline Revenues & 67 & 128 & 205 & 343 & 490 & 279 & 257 \\
\hline Domestic revenues & 10 & 11 & 10 & 11 & 9 & 10 & 9 \\
\hline Petroleum revenue & 46 & 107 & 195 & 330 & 481 & 269 & 248 \\
\hline Grants & 11 & 10 & 0 & 3 & 0 & 0 & 0 \\
\hline Expenditure (cash basis) & 20 & 26 & 32 & 59 & 106 & 101 & 94 \\
\hline Recurrent expenditure & 17 & 19 & 27 & 46 & 70 & 63 & 53 \\
\hline Capital expenditure & 3 & 7 & 5 & 13 & 36 & 38 & 41 \\
\hline Overall balance & 46 & 102 & 174 & 284 & 384 & 178 & 162 \\
\hline Non-oil fiscal balance & 1 & -5 & -21 & -46 & -97 & -91 & -85 \\
\hline \multicolumn{8}{|l|}{ Combined sources fiscal operations $3 /$} \\
\hline Domestic revenue and budget grants & 23 & 24 & 13 & 15 & 11 & 12 & 11 \\
\hline Expenditure & 66 & 67 & 73 & 88 & 144 & 136 & 126 \\
\hline Recurrent expenditure & 50 & 47 & 55 & 66 & 103 & 92 & 80 \\
\hline Capital expenditure & 17 & 20 & 18 & 22 & 41 & 44 & 47 \\
\hline Overall balance & -43 & -43 & -60 & -73 & -134 & -125 & -115 \\
\hline \multicolumn{8}{|l|}{ Money and credit } \\
\hline Broad money (end-period) 4/ & 21 & 23 & 31 & 36 & 39 & $\ldots$ & $\ldots$ \\
\hline \multirow[t]{2}{*}{ Net domestic assets (end-period) } & -38 & -24 & -3 & -43 & -37 & $\cdots$ & $\cdots$ \\
\hline & \multicolumn{7}{|c|}{ (In millions of U.S. dollars) } \\
\hline \multicolumn{8}{|l|}{ External sector } \\
\hline Current account & 64 & 260 & 540 & 1,177 & 2,021 & 1,127 & 1,127 \\
\hline Merchandise exports 2/ & 8 & 8 & 9 & 7 & 14 & 10 & 13 \\
\hline \multirow[t]{2}{*}{ Merchandise imports } & 122 & 112 & 101 & 176 & 353 & 440 & 469 \\
\hline & \multicolumn{7}{|c|}{ (In percent of non-oil GDP) } \\
\hline Current account & 21 & 78 & 165 & 296 & 405 & 191 & 171 \\
\hline Merchandise exports $2 /$ & 3 & 2 & 3 & 2 & 3 & 2 & 2 \\
\hline Merchandise imports & 40 & 34 & 31 & 44 & 71 & 75 & 71 \\
\hline \multicolumn{8}{|l|}{ Memorandum item: } \\
\hline Petroleum Fund balance (percent of non-oil GDP) 5/ & 5 & 112 & 310 & 525 & 841 & 866 & 940 \\
\hline
\end{tabular}

Sources: Data provided by the Timor-Leste authorities; and IMFaff estimates.

1/ Includes locally paid compensation of UN peacekeeping mission staff.

2/ Excludes oil/gas sector.

3/ Includes autonomous agencies and quasi-fiscal expenditure by donors outside the central government budget. The revenue decline in

2005 reflects the creation of the Petroleum Fund to which all oil revenue now accrues. Income from the fund and donor assistance finances the deficit.

4/ Excludes currency holdings by the public, for which no data are available.

5/ End-period. Figure for 2004 refers to the Timor-Sea account, which preceded the August 2005 establishment of the Petroleum Fund. 


\section{Statement by Arrigo Sadun, Executive Director for the \\ Democratic Republic of Timor-Leste, and \\ José Cardoso, Advisor to Executive Director}

July 22, 2009

On behalf of the Timorese authorities, we thank staff for the insightful 2009 Article IV and Selected Issues reports, and for the constructive dialog. The authorities regret the Fund's decision of terminating the position of Resident Representative in Timor-Leste (closed in the end of June). We would like to express the authorities' appreciation for the competence and personal engagement of the Fund's Resident Representative, and to wish him success in his new tasks at the Fund. The Fund's technical assistance is extremely valuable in Timor-Leste and the authorities expect, under the new circumstances, a deeper engagement of the Fund given the extremely challenging endeavors that Timor-Leste faces ahead.

\section{Introduction}

Since the last Article IV consultation one year ago, food security and social cohesion have improved notably, and these short-term priorities were successfully accomplished. "What a difference one year makes", could be the phrase that best characterizes the recent evolution in Timor-Leste. However, the underlying fragility of this post-conflict country remains latent pending the consolidation of these achievements, given the fact that food security is a continuously moving target (although its most severe impact is already over with the end of the food price crisis), and social cohesion is very much dependent upon the development of a sustainable non-oil economy and the reduction of unemployment (especially among the urban youth).

Considering the past adverse circumstances, the low ranking of Timor-Leste in terms of competitiveness is understandable, even by the standards of other low-income countries. However, the authorities' successful achievement of stability has created the social foundations for non-oil development, which is constrained however by the still inexistent economic pillars of a land law (in order to facilitate bank lending and private investment) and basic infrastructures - a necessary condition to raise the development of non-oil economic activities. Therefore, the focus of the authorities is now centered on the development of an ambitious program of infrastructure projects, and 2009 has been nationally declared the "Year of Infrastructure". Public investment in infrastructure has shown to be, in all countries in the world, an important engine for growth and employment creation. It comprises a very expensive public intervention, but one that is known to be profitable for future generations. 


\section{Economic overview}

\subsection{Impact of the fuel and food crisis, and of the global economic crisis}

The impact of last year's fuel and food crisis was very significant in Timor-Leste. As an oil exporting country, the oil price hike recorded last summer - along with an increase in production volumes and in earnings from the Petroleum Fund - boosted the central government's petroleum revenue. However, at the same time, Timor-Leste is one of the least developed countries in the world and, excluding the Petroleum Fund, is also one of the poorest countries in the world. Given the fact that the Timorese people spend a very large share of their income (about 60 percent) on food items, the food price hike prompted the government to prevent the threat of famine and to provide food security by importing large quantities of rice for subsidized resale, which in turn constituted a heavy burden to the budget. With the drop in fuel and food prices from last summer's peak, these effects have reversed and, consequently, have reduced both the burden to the budget of the government's intervention and also the central government's petroleum revenue.

The direct impact of the current global economic crisis has been limited in Timor-Leste. With foreign investment and non-oil exports still at very low levels, and with a financial sector at an embryonic stage, the key channels through which the crisis has spread across the globe - trade, investment, and financial products - have played little or no role in TimorLeste's economy. As for the banking sector, the foreign parent banks of the three commercial branches operating in Timor-Leste present a strong financial position, with two of them in the Global Finance ranking of the world's 50 safest banks.

At present, Timor-Leste faces a financing challenge of how to cope with the country's pressing development bottlenecks and poverty reduction needs. The current juncture of lower oil prices, if it persists, could reduce the estimated sustainable income and, consequently, the budgetary petroleum revenue (which accounts for about 97 percent of all budgetary revenue). Therefore, the authorities have considered, and will further consider, all possible financing options, taking into consideration, as in the past, the country's absorptive capacity constraints and the goal of price stability.

\subsection{Government's current financing strategy}

Until now, the country has relied on its own resources and avoided embarking on an external borrowing strategy. The Petroleum Fund Law allows drawings to exceed the estimated sustainable income, if necessary and justifiable as being in the long-term interest of the country, under approval by the parliament, through a highly responsible and transparent process. To finance and fully implement the ambitious program of the 2009 Budget, the government requested parliamentary approval to withdraw up to $\$ 589.8$ million from the Petroleum Fund ( $\$ 181.2$ million in excess of the estimated sustainable income). The request complied with all the legal requirements defined in the Petroleum Fund Law. The parliament recognized the request as being in the long-term interest of the country - and therefore profitable for future generations - and approved it. The authorities remain committed to the principles of fiscal sustainability and inter-generational equity. 


\subsection{Macroeconomic outlook: results in 2008 and projections for 2009}

Under the above explained circumstances and financing framework, the authorities were able to deliver a significant improvement in the execution rates of capital expenditure, and to effectively implement long-standing difficult measures. Additionally, we also highlight the fact that so far the Government has not drawn resources from the Petroleum Fund for budget support in excess of the estimated sustainable income.

The real non-oil GDP growth rate recorded a consecutive new high in 2008, reaching almost 13 percent. The main driving forces were the significant improvement of security conditions, the rebound in agriculture from the 2007 drought, and the substantial increase in public spending. Official dollarization has served the country well and has helped contain inflationary expectations. Additionally, the appreciation of the US dollar vis-à-vis the Indonesian and Australian currencies has led to a real exchange rate appreciation, which further contributed to abate inflationary pressures. Therefore, after last year's inflation peak due to the food crisis (food represents 60 percent in the CPI), inflation abated to less than 4 percent (year-on-year) in June, and is expected to remain at low levels.

Regarding the fiscal position, the central government's surplus peaked at its highest level ever, reaching 384 percent of non-oil GDP in 2008. The central government's petroleum revenue almost doubled in 2008 to $\$ 2.4$ billion (close to 5 times non-oil GDP). This outcome reflected the surge in international oil prices in the first half of 2008 and, to a lesser extent, the 15 percent increase in production volumes and the doubling in earnings from the Petroleum Fund. For 2009, the significantly lower oil prices will be felt. Timor-Leste is expected to continue recording comfortable surpluses, although not as high as last year. Regarding capital expenditures, the successful improvement in its execution rates should not be confused with any lesser commitment to fiscal soundness from the authorities, but with the authorities' strong determination in implementing the necessary measures. The same reasons explain the evolution in the external position. In 2008, the current account surplus also peaked, recording a figure four times non-oil GDP, but for 2009 the surplus is expected to be far below this level, although still at a comfortable level close to two times non-oil GDP.

\subsection{Macroeconomic guidelines for 2010}

For 2010, the authorities have set a fiscal envelope - a document whose purpose is to guide the preparation of the 2010 Budget - that will restrain fiscal expenditure for 2010 below the level budgeted for 2009. The fiscal envelope - agreed by the ministries for each Organ of State - specifies the maximum amount of funding each Organ of State may receive in 2010. It entails significant cuts in appropriations for goods and services (30 percent) and minor capital (65 percent) relative to the 2009 Budget, while allowing for an increase in capital investment. Wages and salaries will be maintained at the levels of the 2009 Budget.

Therefore, the fiscal envelope will force an effective prioritization of all existing activities and proposed new activities under the authorities' national priorities. We note from the staff's report that the 2010 fiscal envelope is consistent with the staff's "strong policy" scenario. 


\section{Poverty reduction and structural reforms}

\subsection{Poverty reduction, and economic and legislative reforms}

Between 2001 and 2007, the percentage of Timorese people living in poverty increased from 36.3 to 49.9 percent of the overall population, thus increasing the number of poor people to half a million. From this number, about half are children suffering from malnutrition and from being underweight. Under such a reality, it was necessary to implement decisive measures to prevent famine and assure food security. Additionally, pacification measures were implemented, which finally created the conditions for social cohesion. These social measures involved financial support to (i) veterans, elderly, and those disabled, (ii) the return of some 100,000 internally displaced persons (IDP's) to their homes, and (iii) the reintegration of some 800 petitioners from the 2006 rebellion into military and civilian life. All these measures represented a significant burden to the budget, and constituted a necessary step to reduce poverty and create the fundamental conditions for the development of non-oil activities. However, the country still lacks basic infrastructure and a land law.

The establishment of a land law is never an easy task and, in the case of Timor-Leste, it is even more complicated given the rooted mindsets of ancient practices. On top of it, TimorLeste had three decades in almost permanent conflict. Being a post-conflict country, there is the risk that an inadequate land law may not only compromise poverty reduction, but also trigger consequences far beyond its failure, and once again ignite social tensions that could undermine the recently achieved social cohesion. Therefore, for the land law to be successful, it will be necessary to build a strong national consensus around the substance of the law. Under these guidelines, the authorities decided to start a public consultation process on the Draft Law to Establish the Special Regime for Attributing Property Rights (Draft Land Law). The goal is to consult the Timorese people about the Draft Land Law, and to sound the public opinion before the Draft is sent to the council of ministers and then to the parliament later this year. During the public consultation, the civil society will have the opportunity to comment on this Draft, which sets out the proposal for establishing a special legal regime that will allow the government to determine and award first-time property ownership rights to land in Timor-Leste. The public consultation was launched in June and will continue through August, reaching the entire country.

The land law will have a significant impact at all levels, but there are other important reforms to undertake, such as strengthening banking sector regulation and supervision, and developing an insurance sector. The authorities are also considering ways to reduce the cost of credit, either directly or in cooperation with private financial institutions. Finally, significant steps to improve the business environment have recently been taken, like the one-stop-shop for investors, but important measures are still necessary in the judicial area.

The authorities have paid great attention to organizational reforms, such as the decentralization of fiscal operations, which has given the ministries greater autonomy and accountability. As a result, domestic tax revenue has increased along with an expanded base (despite the tax rate cuts implemented in mid-2008 with the tax reform), and the execution rates of the capital budget improved significantly. At the same time, the authorities have further strengthened transparency by completing the move to a cash-based budget system, eliminating the practice of carry-overs, and developing a medium-term fiscal framework. 


\subsection{Investment strategy of the Petroleum Fund}

The Petroleum Fund of Timor-Leste has been one of the world's best performing sovereign wealth funds over the past year. However, while investing in US government bonds proved to be a good investment last year, it is now appropriate to diversify the investment portfolio.

Accordingly, in June the Timorese authorities appointed the Bank for International Settlements (BIS) as the Petroleum Fund's first external manager. The BIS will be responsible for the management of $\$ 1$ billion of Petroleum Fund resources. With this arrangement, the Petroleum Fund will also be invested in longer-term US Treasury Notes as well as bonds issued by other foreign governments. The appointment of the BIS as the Petroleum Fund's first external manager is the initial step in the government's aim to diversify the investment portfolio of the Petroleum Fund in order to increase its expected return and better diversify risks.

The appointment of the BIS as the Petroleum Fund's first external manager respects the Petroleum Fund Law and all the transparency requirements that characterize the Petroleum Fund. Additionally, according to the Petroleum Fund Law, in 2010 (five years after the establishment of the Petroleum Fund) the authorities should undertake a deep review of the Petroleum Fund's investment strategy. By then, the authorities will consider an even more diversified investment strategy while maintaining the basic principles of Petroleum Fund management.

\subsection{Government's potential alternative financing strategy}

As an alternative or a complement to the use of supplemental resources from the Petroleum Fund, a strategy of foreign borrowing could be considered. The authorities recognize that the impact on the country's net wealth could be the same between foreign borrowing and drawing resources from the Petroleum Fund. Foreign borrowing could be even more favorable if based on concessional terms. Additionally, if technical assistance is attached, foreign borrowing could also assist implementation of major infrastructure projects.

If the authorities opt for foreign borrowing, they will pay close attention to its sustainability and will ensure that such borrowing (i) is adequately concessional, (ii) delivers a net positive rate of return by taking into account all costs (including non-interest costs), and (iii) is consistent with macroeconomic stability. Timor-Leste does not yet have the necessary management capacity to implement a foreign borrowing strategy. Therefore, technical assistance would be necessary to start this financing strategy.

\section{Final remarks}

The latest achievements have created the basic social conditions for the development of nonoil activities. However, the underlying fragility of this post-conflict country remains highly visible in very worrisome levels of poverty. The authorities are determined to continue the implementation of a very ambitious reform agenda in order to develop the country and profit both the current and future generations, and they invite the international community's involvement in the current momentum. 